\title{
17. OPAQUE MINERALOGY OF THE IGNEOUS ROCK SAMPLES FROM DSDP HOLE 395A
}

\author{
H. Paul Johnson, Department of Oceanography, University of Washington, Seattle, Washington
}

\section{INTRODUCTION}

Study of the opaque mineralogy of submarine basalts, though essential to understanding the magnetic properties of these units, has not progressed as rapidly as similar studies on subaerial igneous rock samples. The major reason for this has been the predominant recovery of pillow basalts from the ocean floor. The extremely small grain size of the opaque minerals from those quenched rock units has precluded any detailed study of their structure, composition, and alteration features. The recovery, during Leg 34 , of some coarsegrained massive flow units from the Nazca plate, has permitted the beginning of detailed opaque mineralogy studies similar to those that have been carried out on subaerial igneous rocks for the last 10 or 15 years (Ade-Hall et al., 1976; Johnson and Hall, 1977). Leg 45 drilling penetrated close to 600 meters of oceanic igneous basement at Site 395 near the Mid-Atlantic Ridge at $23^{\circ} \mathrm{N}$. A number of relatively coarse-grained units were recovered, as well as abundant fine-grained pillow basalts in which the grain size distribution of the opaque minerals was well within the useful range of the reflecting light microscope. This report gives a detailed description of the opaque mineralogy of 60 polished sections of igneous rock samples from Hole $395 \mathrm{~A}$, and correlates these optical properties with the rock magnetic data obtained from the same samples.

A number of studies of submarine basalts have shown that the major magnetic mineral in both extrusive and intrusive submarine basalts is titanomagnetite that contains between 55 per cent and 65 per cent ulvospinel in solid solution with magnetite (Carmichael, 1970; Irving et al., 1970; Marshall and Cox, 1972; Hall and Fischer, 1977; Johnson and Hall, 1977). In most cases, but not all, these titanomagnetite grains oxidize at low temperature to cation-deficient titanomaghemite phases (Irving, 1970; Marshall and Cox, 1972; Johnson and Merrill, 1973). In pillow basalts exposed to seawater circulation, substantial alteration can take place in as little as a half-million years (Johnson and Atwater, 1977). The major opaque phase in the drill core samples in this study is made up of titanomagnetite/titanomaghemite grains with an average composition of $x=0.60 \pm 0.05$ in $\mathrm{Fe}_{3-\mathrm{x}} \mathrm{Ti}_{\mathrm{x}} \mathrm{O}_{4}$ (Johnson and Melson, this volume). Most of these grains have also been subjected to various degrees of low-temperature oxidation, and the main effort in this

I Contribution No. 978 from the Department of Oceanography, University of Washington, Seattle, Washington. study will be to describe some of these alteration effects and their relationship to the magnetic properties of the core samples.

In addition to low-temperature $\left(4^{\circ} \mathrm{C}\right)$ oxidation and alteration, some of the samples from the Hole 395A cores have been exposed to the intermediate-temperature alteration that results in a characteristic granulation texture. This texture is probably the sub-microscopic phase separation described by Ade-Hall et al. (1971). A few samples, particularly the two dolerite intrusions and a reheated breccia zone, show the characteristic high-temperature oxidation features described by Ade-Hall et al. (1968) and Wilson et al. (1968).

\section{EXPERIMENTAL METHODS}

The major instrument used in this study was the Zeiss reflecting light microscope at the U.S. Geological Survey, Golden, Colorado, which was fitted with polarized light attachment and oil immersion lenses. Magnifications varied from $\times 400$ to $\times 1000$. Sample preparation of the polished sections was done at room temperature, to avoid the changes in alteration of the opaque minerals that can occur at even the moderately elevated temperatures normally used to prepare thin sections. It should be noted that the color of opaque minerals can vary widely, depending on whether air or oil immersion lenses are used, and on the microscope, the type of light source, the type of filter, and the observer. All observations in this report are the author's, and were using oil immersion; they are consistent with previous descriptions of submarine basalts (Ade-Hall et al., 1976). Curie temperatures were measured in a Cahn recording electrobalance, and all heating was done in an atmosphere of 9 per cent hydrogen and 91 per cent nitrogen at atmospheric pressure (Johnson, this volume).

In order to define several terms used in the opaque mineralogy descriptions that follow, it is convenient to divide the alteration of the opaque minerals of submarine basalts into three categories which depend on the temperature at which this alteration took place. Lowtemperature oxidation is taken to mean that alteration of titanomagnetite to titanomaghemite which occurs at temperatures below $100^{\circ} \mathrm{C}$ and generally at ambient seawater temperatures of $4^{\circ} \mathrm{C}$. The result of this lowtemperature oxidation is much more complex than the simple oxidation of ferrous to ferric ions. It also includes grain subdivision by the formation of cracks, iron migration out of the lattice, and partial replacement of the opaque minerals by non-opaque material. 
The various stages of low-temperature oxidation have been described by Johnson and Hall (in press), and are only briefly summarized below.

Stage 1: unoxidized titanomagnetite.

Stage 2: brightening around the edges of the grain boundaries.

Stage 3: formation of curvilinear cracks.

Stage 4: partial replacement of the material in the widened cracks by non-opaque material.

Stage 5: almost complete replacement of the opaque grain by non-opaque material.

The features of Stages 2 and 3 are sometimes found together in the same grain, but in general the above is an evolutionary series of features associated with lowtemperature alteration. An additional feature of lowtemperature alteration is the apparent migration of iron out of the titanomagnetite/titanomaghemite lattice during oxidation (Johnson and Melson, this volume). This migrating iron sometimes forms a red or yellowred stain in the silicate phases that surround the opaque grains. The presence of this feature in the following descriptions is referred to as "red staining of the groundmass.',

The presence of intermediate-temperature granulation features in the opaque grains of submarine basalts seems to be fairly rare. This type of alteration, which can be associated with zeolite facies metamorphism, takes place between $150^{\circ} \mathrm{C}$ and $300^{\circ} \mathrm{C}$, and is probably a submicroscopic phase separation of the oxidized titanomaghemite as it breaks down to a low-titanium magnetite and some high-titanium phases (Ade-Hall et al., 1971). In the Leg 45 samples of this study, this type of granulation was observed only in one sample of recrystallized gabbro.

High-temperature oxidation of titanomagnetite grains is very common in continental intrusive and extrusive igneous rocks. The sequence of alteration features for this type of high-temperature oxidation has been extensively studied (Ade-Hall et al., 1968; Wilson et al., 1968). The series of alteration features depends heavily, for identification of the early oxidation classes, on the presence of ilmenite lamellae along the (111) planes of the host magnetite grains. These well-formed ilmenite lamellae probably do not occur unless the temperature of oxidation (or subsequent reheating) takes place around $400^{\circ} \mathrm{C}$ or higher. The oxidation classes given by Ade-Hall et al. (1968) are summarized below.

Class 1: no ilmenite lamellae, single-phase titanomagnetite.

Class 2: rare exsolved ilmenite lamellae along the (111) planes of the magnetite phase.

Class 3: abundant ilmenite along the (111) planes of the magnetite phase.

Class 4: partial decomposition of both the magnetite grains and ilmenite lamellae to hematite and other titanium-rich phases.

Class 5: the original ilmenite lamellae completely replaced by hematite, rutile, and, occasionally, pseudobrookite.

Class 6: the entire original opaque grain replaced by aggregates of hematite, rutile, and pseudobrookite.
These high-temperature oxidation features, similar to granulation textures, are rarely found in the upper layers of submarine igneous basalts. In the Leg 34 Nazca plate studies previously described, the bottom unit of Hole 157 showed well-developed ilmenite lamellae, as did some opaque grains associated with a deuteric altered crack in a massive flow from Hole 319 (Ade-Hall et al., 1976). In general, however, these high-temperature oxidation features seem to be associated only with special areas that have both a high oxygen fugacity and a high-temperature environment for a length of time sufficient for well-developed ilmenite lamellae to form. The results of the present study are in agreement with this.

\section{RESULTS}

Descriptions of the opaque mineralogy of the Site 395 igneous rock samples appear in the Appendix. As mentioned previously, the major opaque phase in these submarine basalts is a high-titanium, class 1, titanomagnetite ( $60 \%$ ulvospinel) that has been subjected to various degrees of low-temperature oxidation (Figures 1,2 , and 3 ). This mineralogy is sufficiently common that it is more useful to point out the exceptions.

The uppermost basement sections of Hole 395A contain cobbles of ultramafic rocks, including serpenti-

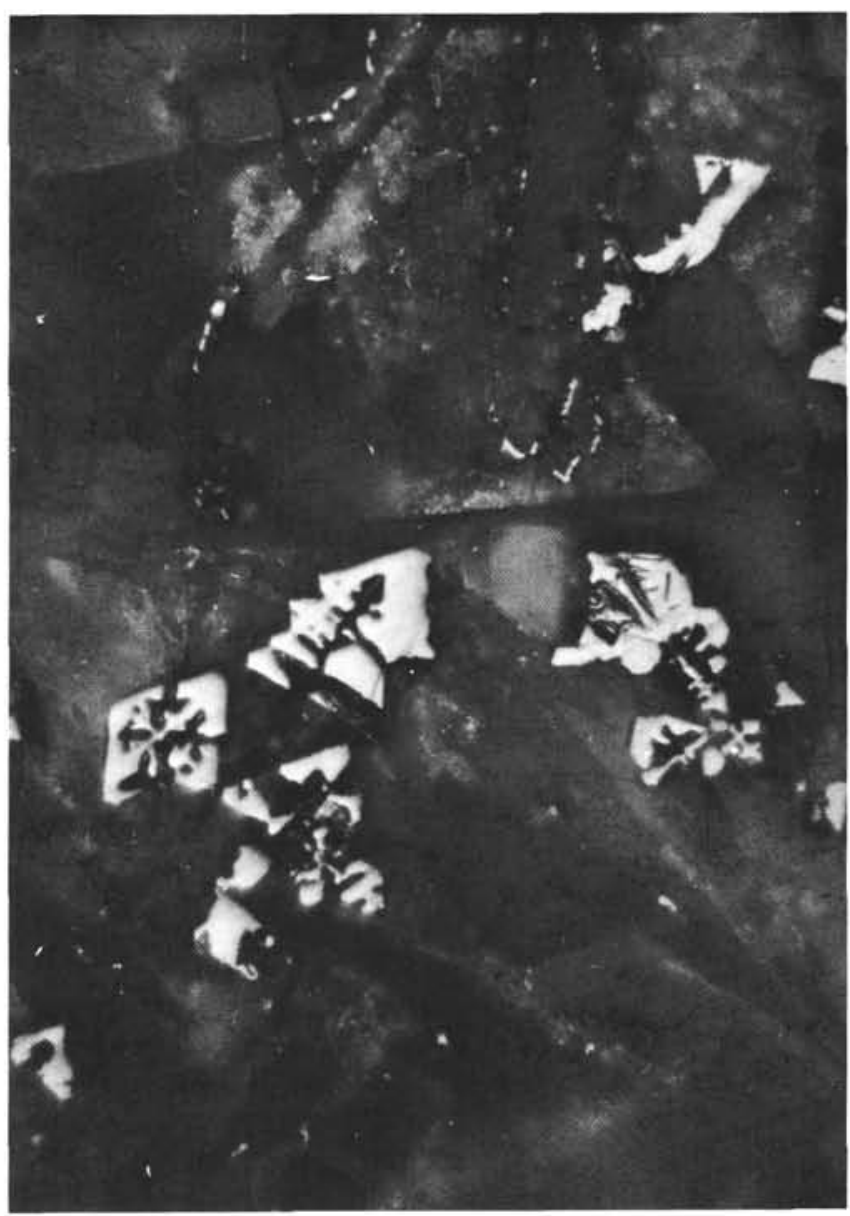

Figure 1. Skeletal grains of slightly oxidized titanomagnetite from Sample 395-22-2, 32-134 cm (9C). 


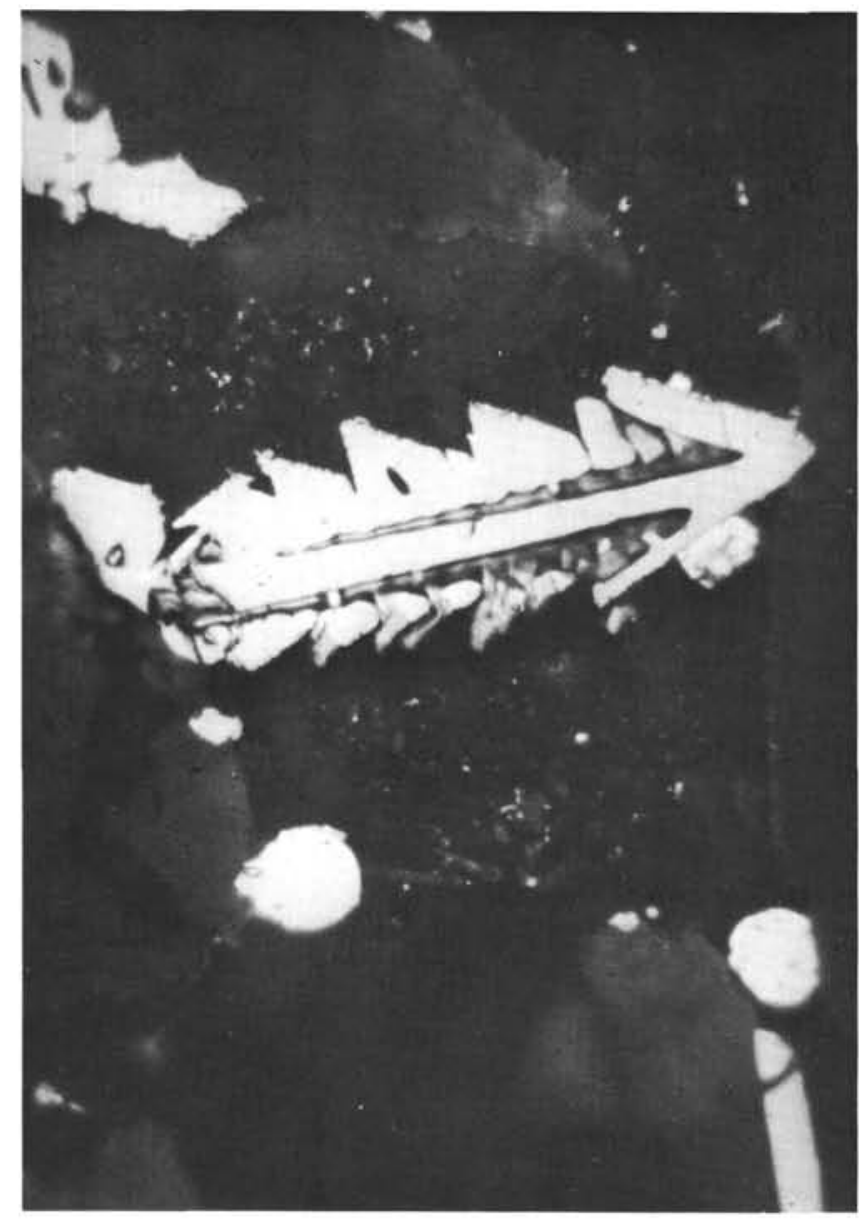

Figure 2. Skeletal grains of unoxidized titanomagnetite from Sample 395A-51-1, 89-91 cm (16B): Round bright globules are pyrite grains.

nized peridotite and recrystallized gabbro. These metamorphosed plutonics show long chain-like grains of titanium-free magnetite, probably derived from breakdown of the parent olivine grains in the original igneous rock. The samples also contain occasional large euhedral grains of titanium-free magnetite with ilmenite exsolution lamellae, similar to continental plutonic rocks. These plutonic samples have undergone a complex alteration history; granulation and partial replacement of the magnetite are fairly common (Figures 3, 4, and 5). Figure 6 shows a former magnetite grain completely replaced by non-opaque material.

Low-titanium magnetite grains containing ilmenite exsolution lamellae also occur in two other portions of the Hole 395A drill core: the upper, carbonate-cemented breccia zone (Cores 32 and 33) (Figure 7) and doleritic intrusions in the lower sections (Cores 62 to 64) (Figures 8 and 9). The fine-grained aphyric unit separating the lower dolerite intrusion from the upper dolerite intrusion also contains magnetite grains with ilmenite lamellae. These high-temperature oxidation features have a pronounced effect on the magnetic properties of the igneous rock samples (Johnson, this volume).

The third occurrence of titanium-free magnetite is produced during low-temperature oxidation of the iron

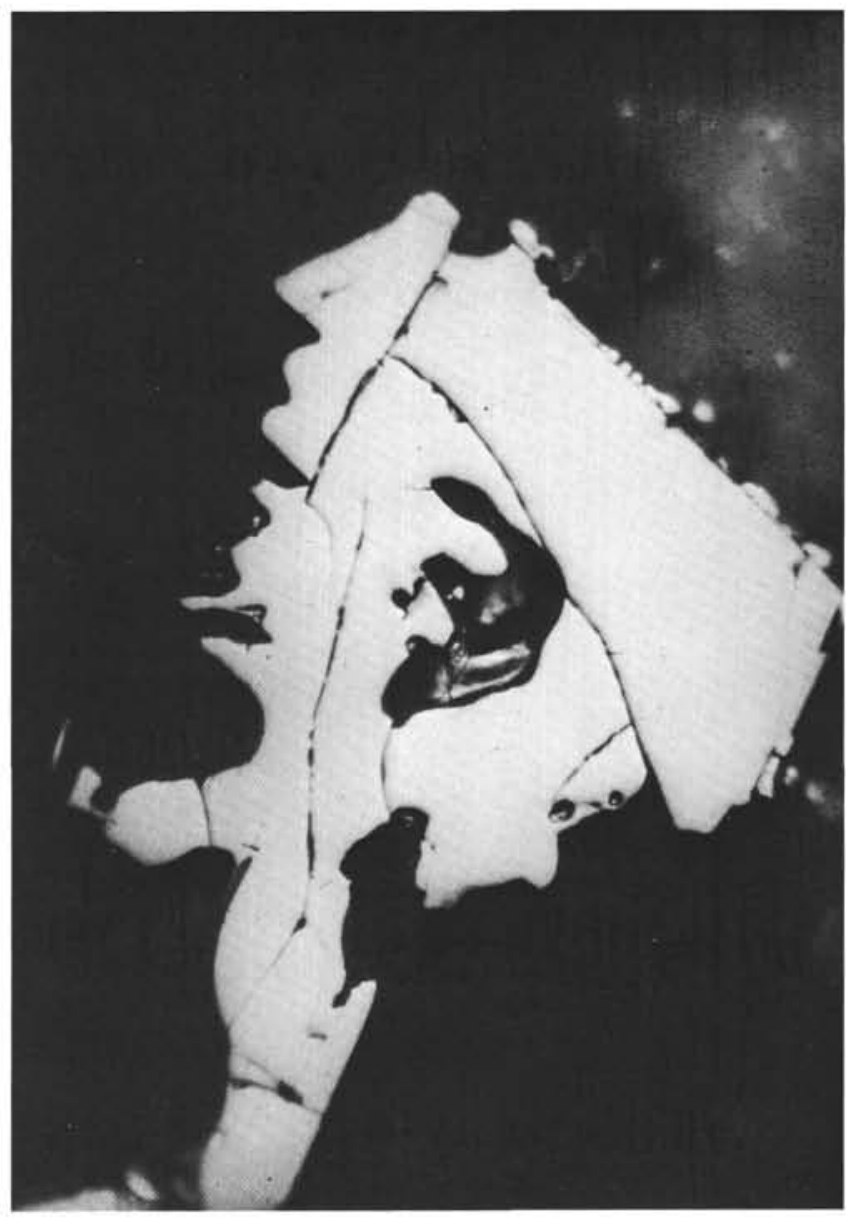

Figure 3. Large skeletal to subhedral grain of titanomaghemite, showing the volume-change cracks associated with stage 3, low-temperature oxidation (Sample 395A$15-2,55-57 \mathrm{~cm})$.

sulfides. These sulfides, generally pyrite and pyrrhotite, undergo low-temperature oxidation stages similar to titanomagnetite grains, and titanium-free magnetite is one of the oxidation products. This alteration has been previously described from studies of the Leg 34 massive basalt units from the Nazca plate (Ade-Hall et al., 1976) and is fairly common in the samples in this study.

\section{Opaque Minerals}

1. Titanomagnetite/titanomaghemite-commonly present in concentrations of 1 per cent to 5 per cent of almost all samples examined in this study; the coarsegrained, metamorphosed, ultramafic cobbles at the top of the Hole $395 \mathrm{~A}$ core are the only exception. Composition of the initial, unoxidized titanomagnetite is $x$ $=0.60 \pm 0.05$ in $\mathrm{Fe}_{3-\mathrm{x}} \mathrm{Ti}_{\mathrm{x}} \mathrm{O}_{4}$.

2. Titanium-free magnetite-only rarely present in these samples, in one of the following contexts: (a) as a product of serpentinization of olivine grains in the serpentinized peridotite samples; (b) as large euhedral grains with pronounced ilmenite lamellae in the ultramafics recovered in the uppermost cores of Hole $395 \mathrm{~A}$; (c) as a product of low-temperature oxidation of sulfide (pyrite or pyrrhotite) grains; (d) as a product of 


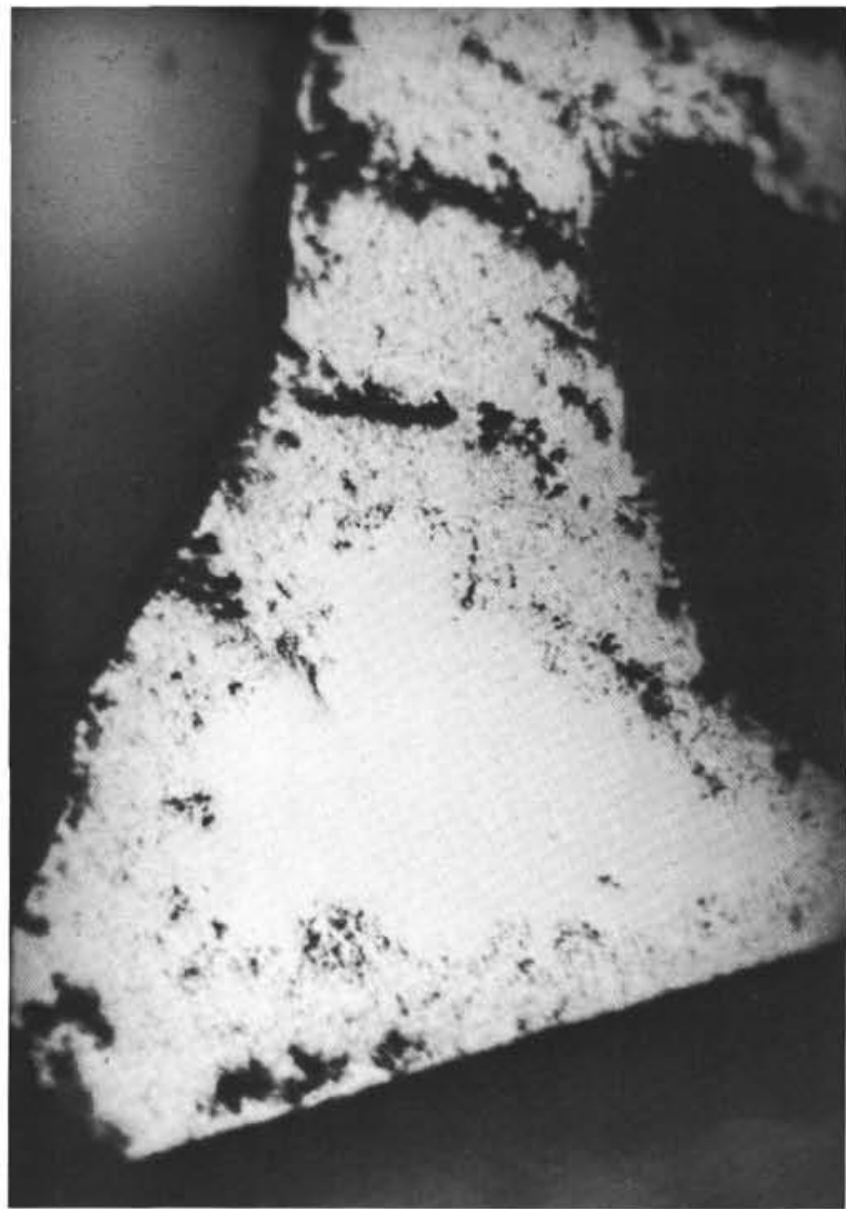

Figure 4. Titanomagnetite grain from a recrystallized gabbro cobble, showing the characteristic submicroscopic phase separation associated with intermediate-temperature granulation (Sample 395A-4-1, 91-93 cm [8]).

high-temperature oxidation of titanomagnetite/titanomaghemite grains during initial implacement (dolerite intrusions), or by subsequent reheating at elevated temperatures (the breccia zone in Core 33 and the aphyric unit between the dolerite intrusions).

3. Ilmenite: (a) present as a separate phase in the extrusive basalts, generally with a distinctive lath-like shape and marked anisotropy under crossed polarizers (Figure 10); (b) also present as ilmenite lamellae along the (111) planes of magnetite-as a high-temperature oxidation product of the initial titanomagnetite grains.

4. Hematite-extremely rare in submarine igneous rocks. Occasionally found as an alteration product in the ultramafics (e.g., the recrystallized gabbro, Sample $395 \mathrm{~A}-4-1,91-93 \mathrm{~cm})$ or in the high-temperaturealtered breccia clasts of Sample 395A-32-1, 54-56 cm, (Figure 11).

5. Sulfides-in general, pyrite and pyrrhotite are commonly found in both the extrusive and intrusive units of the Hole $395 \mathrm{~A}$ core. In the more altered samples, these sulfides can be oxidized to both magnetite and additional non-opaque phases. The red staining

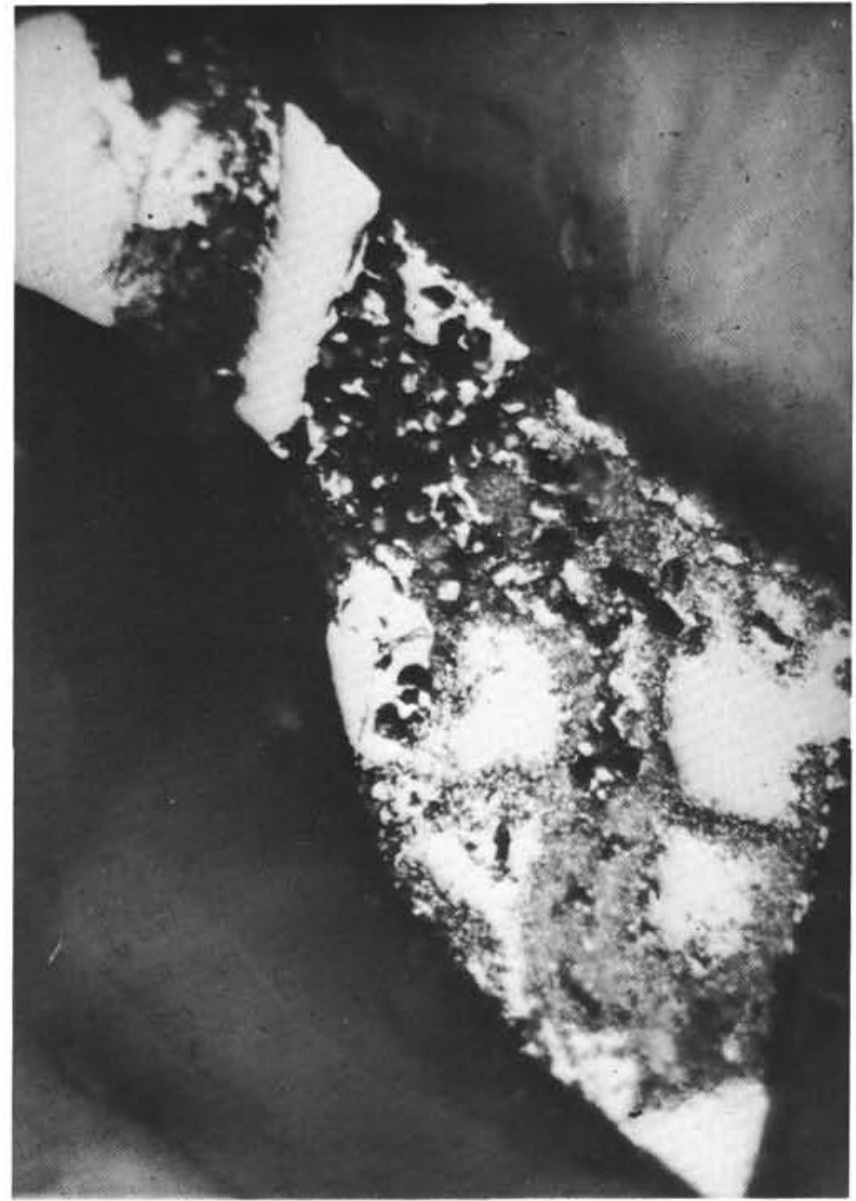

Figure 5. Titanomagnetite grain from the same sample as Figure 6, showing an intermediate stage of replacement of the opaque phase by non-opaque material. The bright bar in the upper left corner is an unaltered ilmenite lamella (Sample 395A-4-1, 91-93 cm [8]).

of the surrounding silicates, often associated with the low-temperature oxidation of titanomagnetite, is also commonly associated with oxidized sulfide grains.

\section{DISCUSSION}

The preceding description and a cursory glance at the Appendix indicate that the principal magnetic mineral in the core samples from Hole $395 \mathrm{~A}$ is a titanomagnetite phase that has been subjected to various degrees of low-temperature oxidation. An evolutionary sequence of microscopic features for the low-temperature oxidation of titanomagnetite in submarine basalts has been proposed and discussed previously (Johnson and Hall, in press). Since for titanomagnetites of relevant composition the Curie temperature rises smoothly (but not linearly) from $150^{\circ} \mathrm{C}$ to approximately $400^{\circ} \mathrm{C}$ with increasing oxidation (Readman and O'Reilly, 1972), a correlation between the presence or absence of the sequential oxidation features with Curie temperature for the samples in the Appendix should allow determination of the degree of alteration necessary to produce a given feature. 


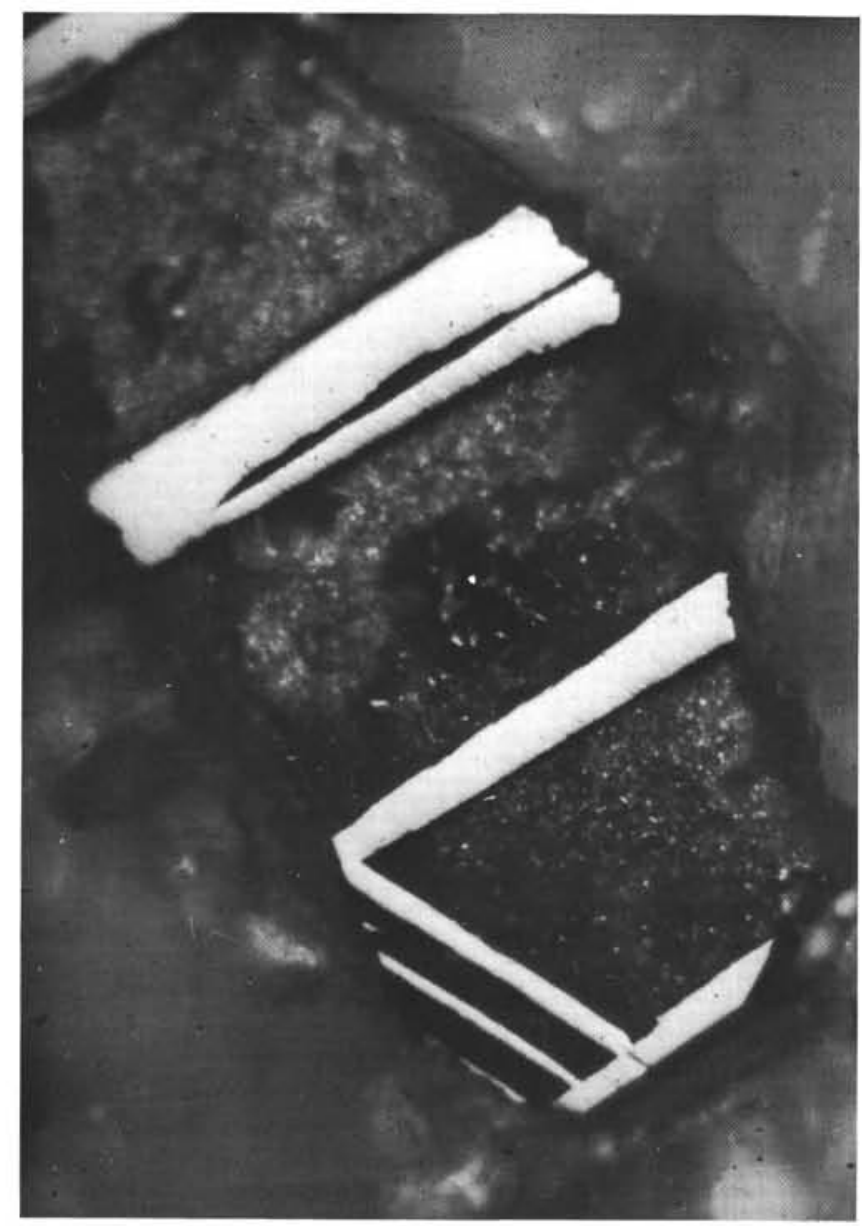

Figure 6. A former magnetite grain that has been completely replaced by non-opaque material, and is only identified by the relict ilmenite lamellae structure (Sample 395A-4-1, 91-93 cm [8]).

Figure 12 is a plot of the percentage of the Hole $395 \mathrm{~A}$ samples that show brightening of color around the grain boundaries or non-uniformity of color throughout the titanomagnetite grains (Stage 2; Johnson and Hall, 1977). The horizontal row of numbers parallel to the Curie temperature axis indicates the number of polished sections examined in each Curie temperature interval. Several complete traverses across a 1-inch-diameter polished section were made for each specimen. If any grains with a particular feature were noted, then the sample was considered to have that feature, for the purposes of Figures 12 through 15. Figure 12 indicates that although none of the samples with Curie temperatures below $175^{\circ} \mathrm{C}$ shows any brightening or discoloration of the grains, most of those with Curie temperatures above $200^{\circ} \mathrm{C}$ do show the features of Stage 2, low-temperature oxidation.

Figure 13 illustrates the same sort of analyses with a plot of the percentage of titanomagnetite/titanomaghemite grains that show the curvilinear volumechange cracking (Stage 3) as a function of Curie temperature. No samples with Curie temperatures less than $200^{\circ} \mathrm{C}$ show any cracking, and most of those

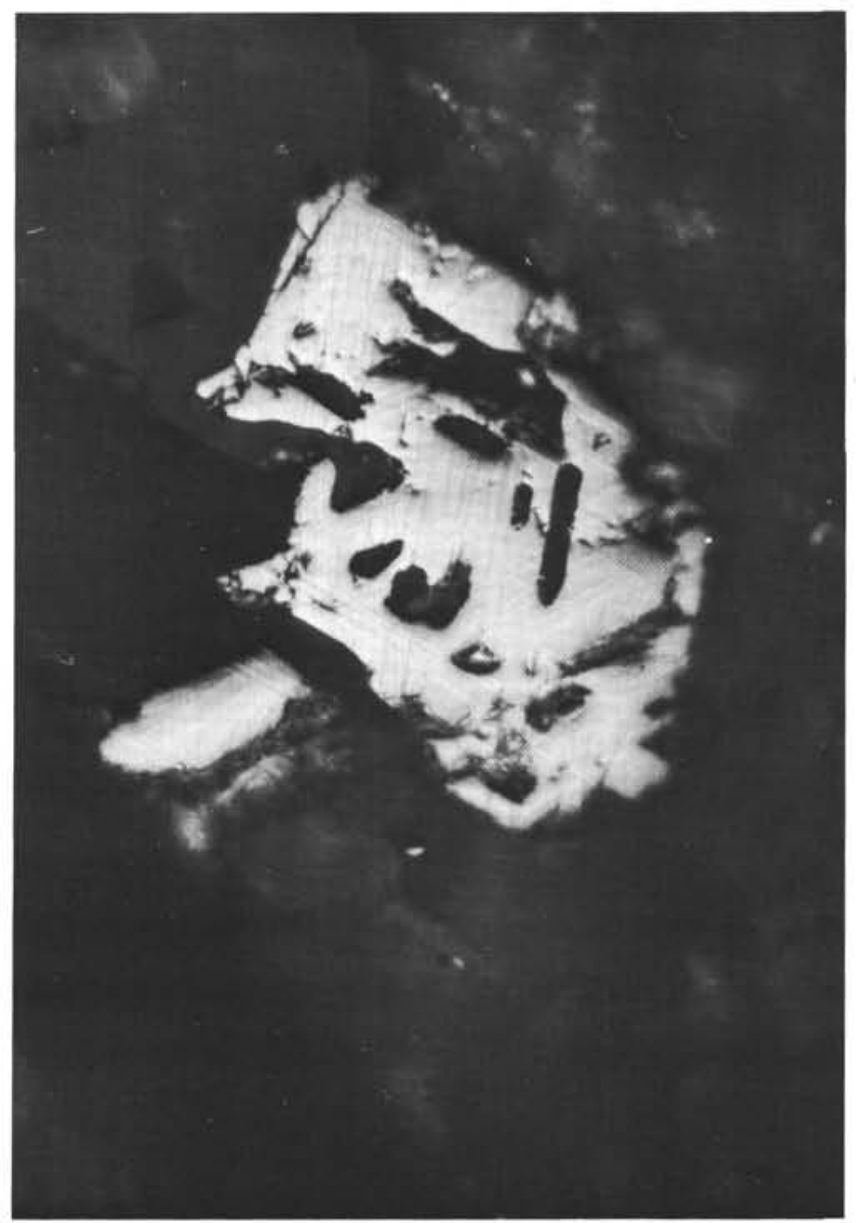

Figure 7. Titanomagnetite grain from a breccia clast from Core 32. The well-formed abundant ilmenite lamellae along the (111) planes of the host magnetite phases indicate that the breccia zone was either emplaced at high temperature or subjected to subsequent reheating (Sample 395A-32-2, 56-58 cm [7A]) (deuteric oxidation, class 3).

samples with Curie temperatures above $225^{\circ} \mathrm{C}$ to $250{ }^{\circ} \mathrm{C}$ do exhibit this volume-change cracking.

Figure 14 is a plot of the percentage of samples that show some form of red, or yellow-red, staining of the silicates surrounding the opaque grains. Identification of this type of staining is somewhat subjective, but most samples with Curie temperatures above $275^{\circ} \mathrm{C}$ exhibit some form of reddish staining. As argued previously, this staining may result from migration of iron out of the titanomaghemite lattice and into the surrounding silicates during oxidation.

Another common feature of submarine basalts is that unoxidized pillow basalts contain abundant primary sulfides, not common in older, more oxidized samples. Figure 15 shows the percentage of samples in which sulfide grains (either pyrite or pyrrhotite) were identified, in several traverses of the polished section, as a function of Curie temperature. This figure should not be taken to indicate that samples with Curie temperatures above $300^{\circ} \mathrm{C}$ will not have any primary 


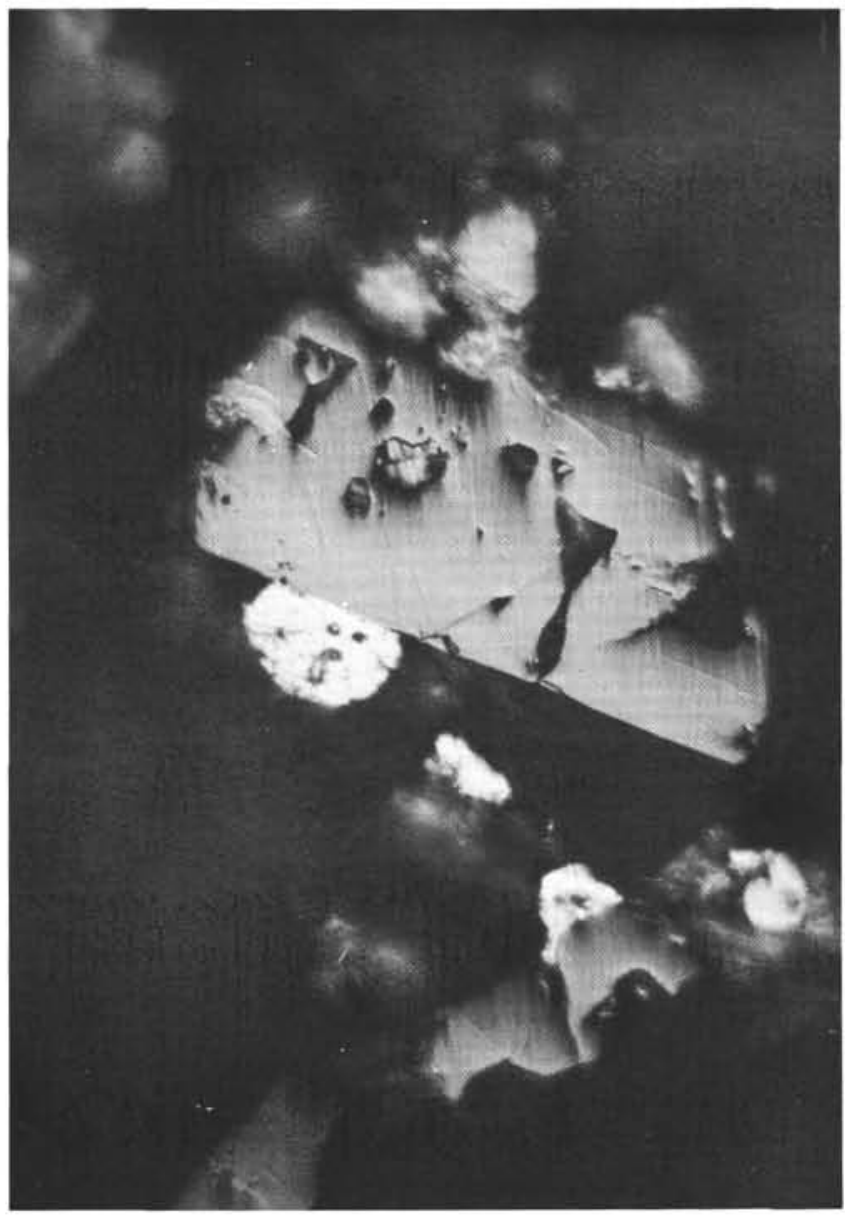

Figure 8. Large grains of titanomagnetite that show the relatively poorly formed ilmenite lamellae associated with moderate amounts of high-temperature oxidation (upper dolerite unit, Sample 395A-61-2, 74-76 cm [5]) (deuteric oxidation, class 2). The bright globular phases are pyrite grains.

sulfides present, but only that the amount of sulfide phases in a given sample seems to decrease with increasing degree of low-temperature oxidation. Since abundant primary sulfides are always present in the fresh pillow basalts from the FAMOUS area (Johnson and Abdel-Aal, in preparation), the decreasing presence of sulfides with increasing degree of oxidation is taken to be an effect of the oxidation.

\section{CONCLUSIONS}

1. Consistent with the results from previous studies on submarine basalts, the principal magnetic mineral in the Hole $395 \mathrm{~A}$ core samples is a titanomagnetite that has been subjected to various degrees of lowtemperature oxidation to titanomaghemite.

2. The occasional presence of well-defined ilmenite lamellae along the (111) planes of magnetite grains indicates that some sections of the Hole 395A core have been exposed to high-temperature $\left(>400^{\circ} \mathrm{C}\right)$ alteration: specifically, (a) the ultramafic cobbles at the top of the core, (b) a remagnetized breccia zone (Cores 32 and 33), (c) sections of both the upper and lower

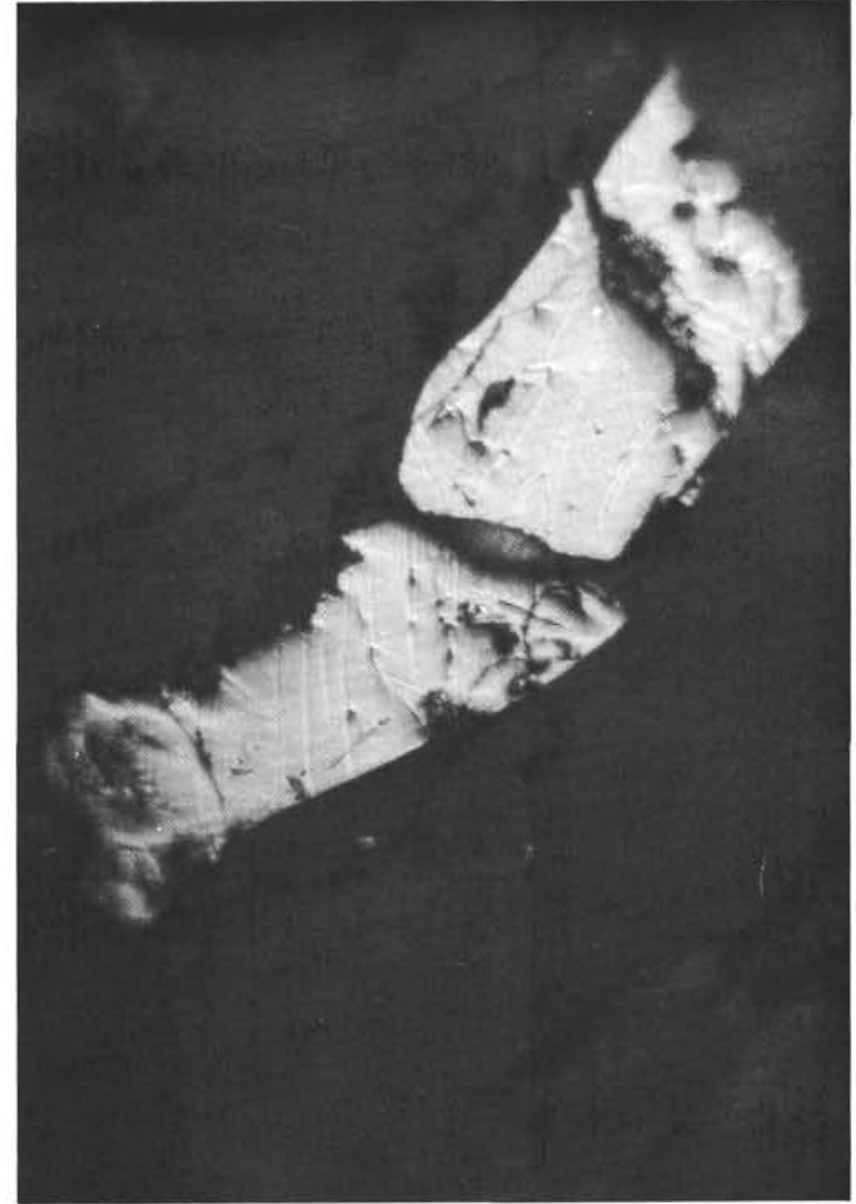

Figure 9. A large titanomagnetite grain from the lower dolerite intrusion, also showing the ilmenite lamellae associated with high temperature oxidation (Sample $395 A-63-4,32-34 \mathrm{~cm}$ ) (deuteric oxidation, class 2).

dolerite intrusions, and (d) the fine-grained aphyric unit between the two dolerite intrusions.

3. The granulation associated with the intermediatetemperature alteration of zeolite facies metamorphism seems to be generally absent from the bulk of samples from the Hole $395 \mathrm{~A}$ core. This seems to imply that most of the upper 600 meters of this section of the oceanic igneous crust has been exposed only to ambient temperatures of less than $100^{\circ} \mathrm{C}$.

4. Comparison of the sequence of microscopic features of the low-temperature oxidation of titanomagnetite to titanomaghemite indicates that, for these submarine basalts, (a) brightening around grain edges occurs in samples with Curie temperatures above $200^{\circ} \mathrm{C}$ (Stage 2); (b) cracking of the titanomagnetite grains commonly occurs in samples with Curie temperatures above $225^{\circ} \mathrm{C}$ to $250^{\circ} \mathrm{C}$ (Stage 3); (c) samples with Curie temperatures above $275^{\circ} \mathrm{C}$ commonly show some sort of red or yellow-red staining of the silicates surrounding the titanomaghemites; (d) the primary sulfide grains in submarine basalts undergo replacement during low-temperature oxidation and decrease in abundance with increasing degree of low-temperature alteration. 


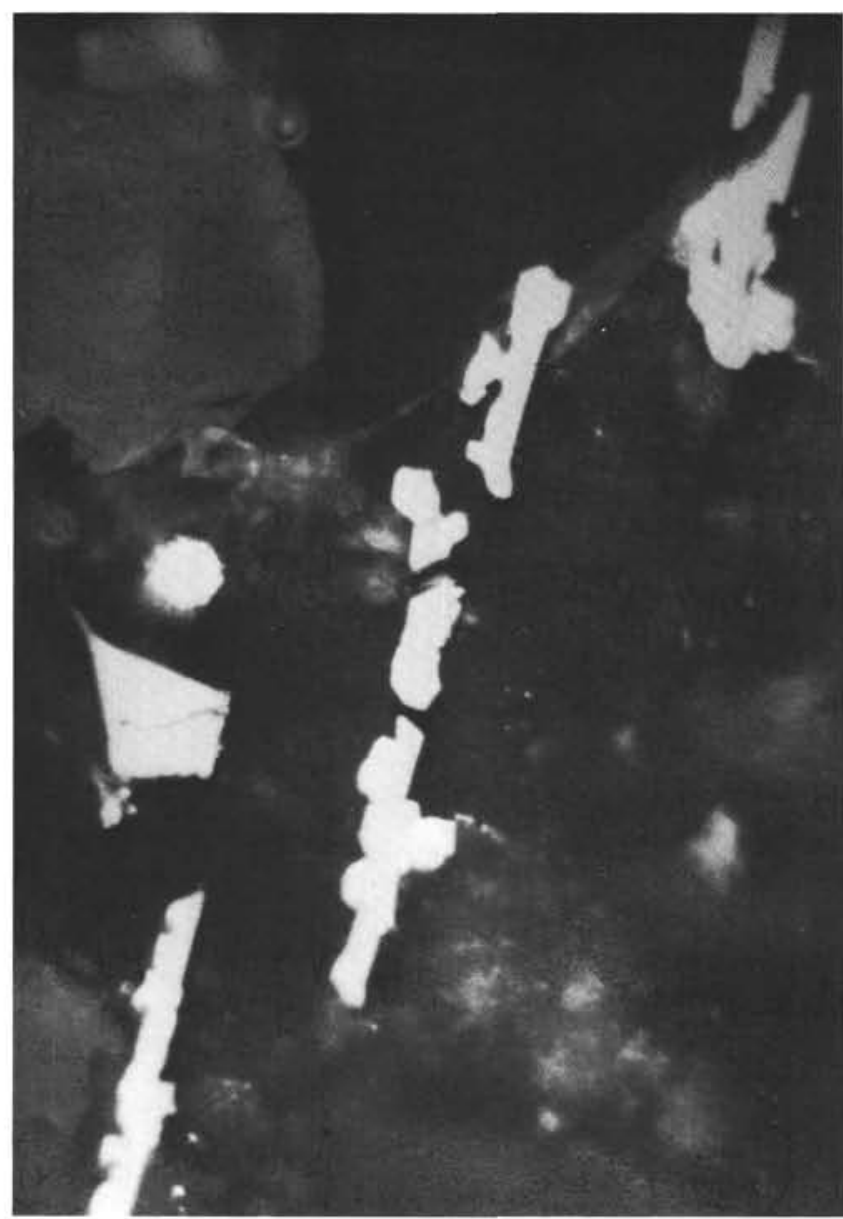

Figure 10. The characteristic laths of ilmenite, typical of ilmenite present in submarine pillow basalts as a separate phase. Unlike ilmenite lamellae within titanomagnetite grains, these ilmenite laths do not imply high-temperature oxidation. (Sample 395A-5-1, 89-91 cm [16B]).

\section{ACKNOWLEDGMENTS}

I would like to thank D. E. Watson and R. Reynolds for the use of their laboratory facilities at the U.S. Geological Survey, Golden, Colorado, during this study. The manuscript was reviewed by J. M. Hall, R. T. Merrill, P. Henshaw, O. Abdel-Aal, and D. Plasse, and their comments are gratefully acknowledged. This research was supported by NSF Grants OCE75-21127 and OCE77-07093.

\section{REFERENCES}

Ade-Hall, J. M., Fink, L. K., and Johnson, H. P., 1976. Petrography of opaque minerals, Leg 34. In Yeats, R. S., Hart, S. R., et al., Initial Reports of the Deep Sea Drilling Project, v. 34: Washington (U. S. Government Printing Office), p. 349-362

Ade-Hall, J. M., Khan, M. A., Dagley, P., and Wilson, R. L., 1968. A detailed opaque petrological and magnetic investigation of a single tertiary lava flow from Skye, Scotland-I Iron-titanium oxide petrology, Geophys. J. Roy. Astron. Soc., v. 16, p. 375-388.

Ade-Hall, J. M., Palmer, H. C., and Hubbard, T. P., 1971. The magnetic and opaque petrological response of basalts to hydrothermal alteration, Geophys. J. Roy. Astron. Soc., v. 24 , p. $137-174$.

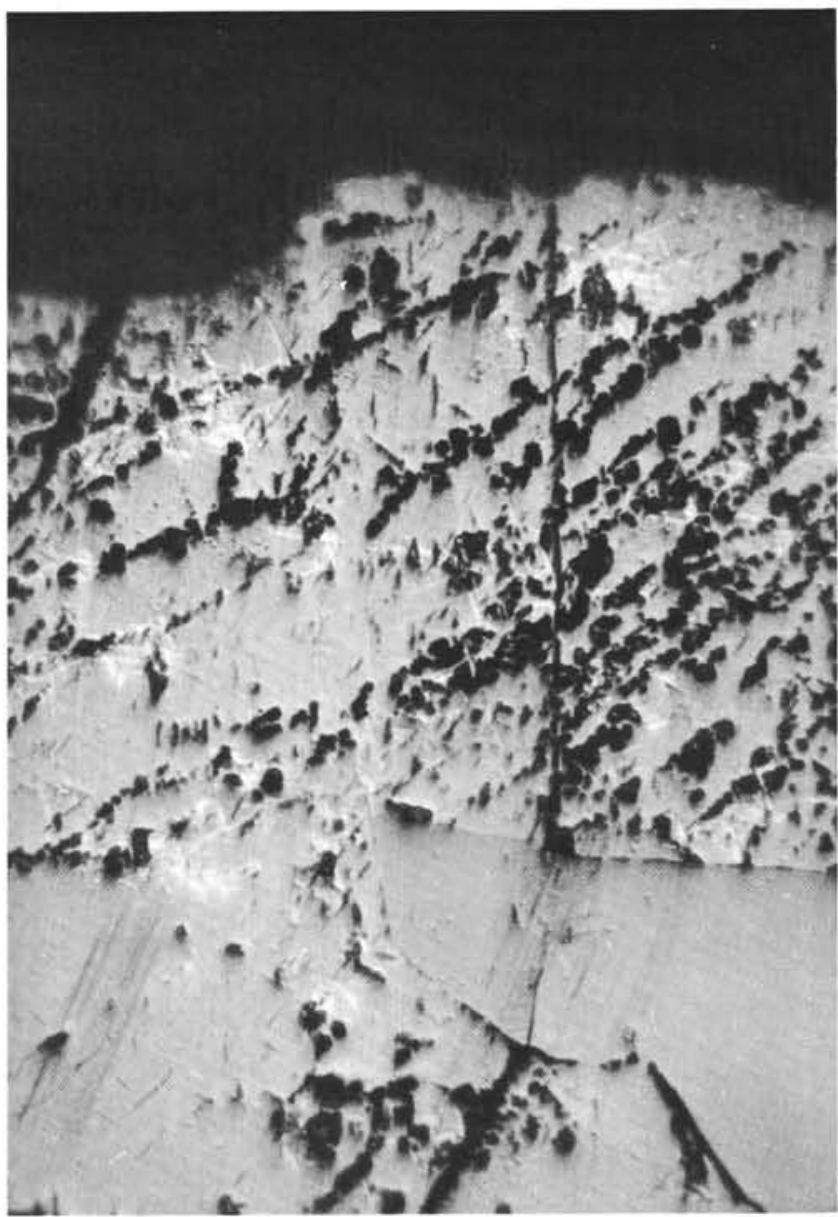

Figure 11. A sample of recrystallized gabbro (Sample $395 A-4-1,91-93 \mathrm{~cm}$ [8]), showing the very rare (in the submarine environment) occurrence of hematite. The hematite grains are the very light gray, almost white, lamellae distributed throughout a light gray magnetite grain. The dark gray unaltered phase in the lower left corner is ilmenite. The black rods in the magnetite grain are probably spinel.

Carmichael, C. M., 1970. The Mid-Atlantic Ridge near $45^{\circ} \mathrm{N}$, magnetic properties and opaque mineralogy of dredge samples, Canadian J. Earth Sci., v. 7, p. 239-256.

Hall, J. M. and Fischer, J. F., 1977. Opaque mineralogy of basement rocks, Leg 37. In Aumento, F., Melson, W. G., et al., Initial Reports of the Deep Sea Drilling Project, v. 37: Washington (U. S. Government Printing Office), p. $857-873$.

Irving, E., 1970. The Mid-Atlantic Ridge at $45^{\circ} \mathrm{N}$, XIV. Oxidation and magnetic properties of basalt: review and discussion, Canadian J. Earth Sci., v. 7, p. 1528-1538.

Irving, E., Park, J. K., Haggerty, S. E., Aumento, F., and Loncarevic, B., 1970. Magnetism and opaque mineralogy of basalts from the Mid-Atlantic Ridge at $45^{\circ} \mathrm{N}$, Nature, v. 228 , p. $874-976$.

Johnson, H. P. and Atwater, T., 1977. Magnetic study of basalts from the Mid-Atlantic Ridge, latitude $37^{\circ} \mathrm{N}$, Geol. Soc. Am. Bull., v. 88 , p. 637-647.

Johnson, H. P. and Hall, J. M., in press. A detailed rock magnetic and opaque mineralogy study of the basalts from the Nazca Plate, Geophys. J. Roy. Astron. Soc. 


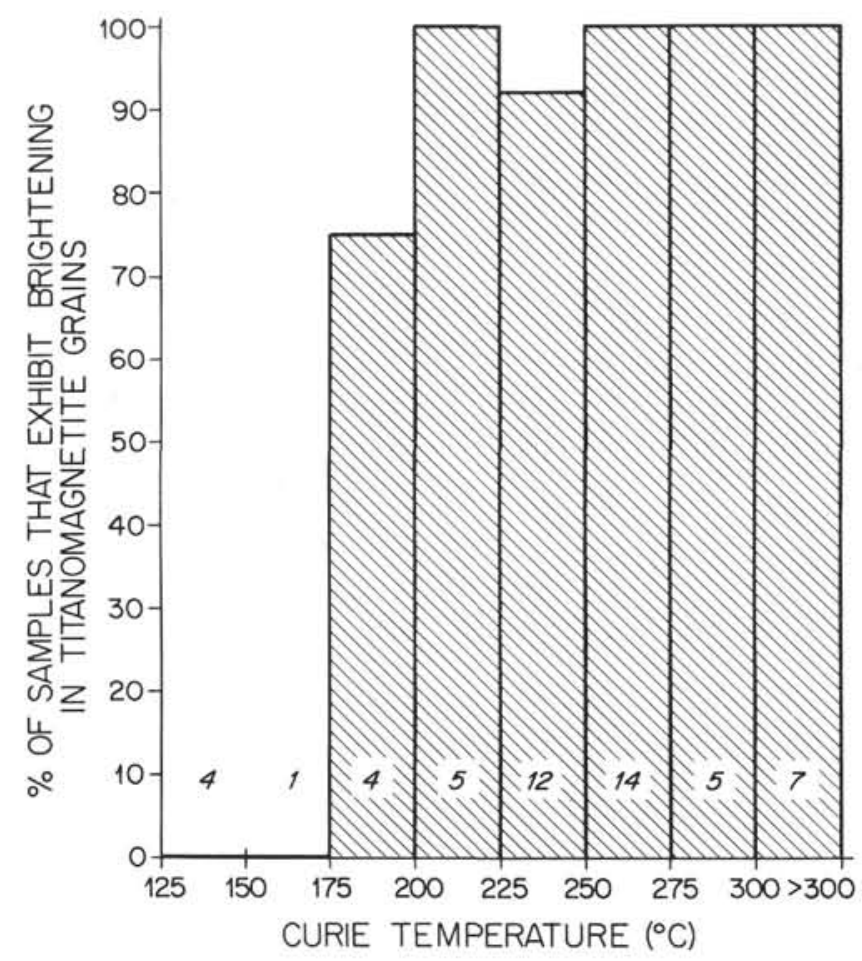

Figure 12. A histogram of the percentage of samples in polished sections from Hole 395 A core that show some brightening or discoloration in the titanomagnetite grains as a function of Curie temperature. The numbers in the row parallel to the horizontal axis indicate the number of polished sections in each Curie temperature interval. None of the samples with Curie temperatures below $175^{\circ} \mathrm{C}$ show any brightening, whereas most of those above $175^{\circ} \mathrm{C}$ show at least some brightening.

Johnson, H. P. and Merrill, R. T., 1973. Low temperature oxidation of a titanomagnetite and the implications for paleomagnetism, J. Geophys. Res., v. 78, p. 4938-4949.

Marshall, M. and Cox, A. V., 1972. Magnetic changes in pillow basalt due to sea floor weathering, J. Geophys. Res., v. 77 , p. 6459-6469.

Readman, P. W. and O'Reilly, W., 1972. Magnetic properties of oxidized (cation-deficient) titanomagnetites ( $\mathrm{Fe}, \mathrm{Ti}$, $\square$,) ${ }_{3} \mathrm{O}_{4}, J$. Geomag. Geoelect., v. 24, p. 69-90.

Wilson, R. L., Haggerty, S. E., and Watkins, N. D., 1968. Variation of paleomagnetic stability and other parameters in a vertical traverse of a single Icelandic lava, Geophys. $J$. Roy. Astron. Soc., v. 16, p. 79.

\section{APPENDIX}

Sample: 395A-3-1, 89-91, cm (2)

Lithologic description: Serpentinized periodotite with talcose veinlets.

Opaque mineralogy: Major opaque mineral is (presumed titanium-free) very light gray magnetite, present as long filaments and chains. These magnetite filaments are 200 to $300 \mu \mathrm{m}$ long and 10 to $25 \mu \mathrm{m}$ wide, on the average. Some red staining of the groundmass occurs around the magnetite, indicating iron migration out of the grains. Rare euhedral grains of magnetite, 50 to $200 \mu \mathrm{m}$ in size, seem to predate the serpentinization. These euhedral grains show no ilmenite lamellae but a granulated texture occurs in some parts of the grains. Both magnetite filaments and euhedral grains look eroded and oxidized, as if the sample had been subjected to alteration after serpentinization.

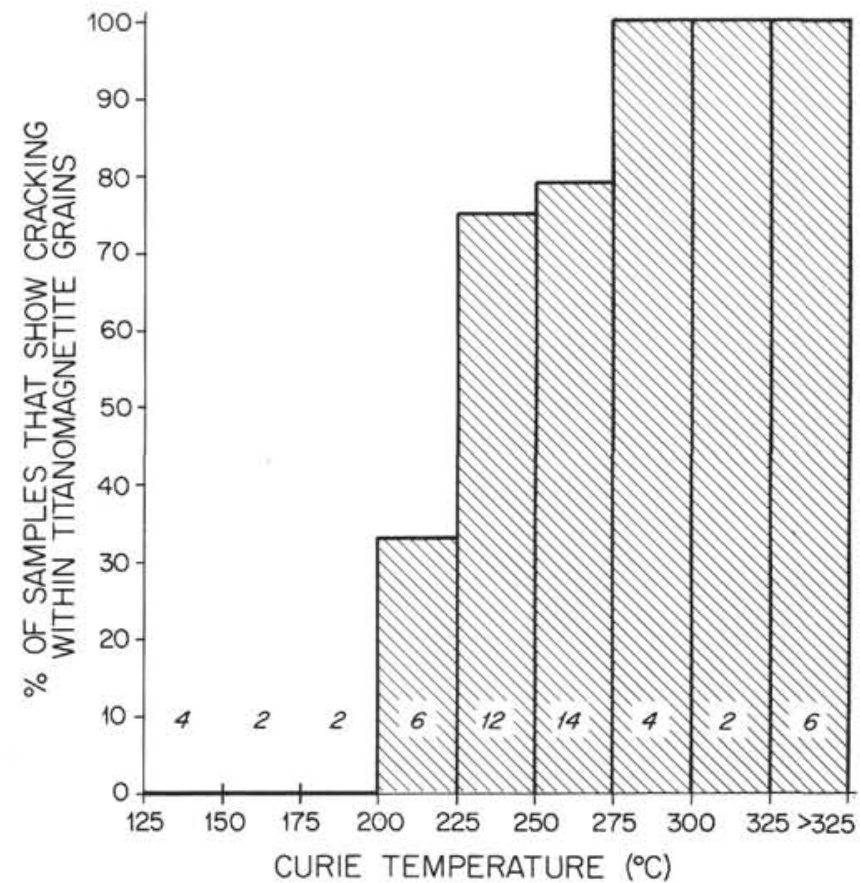

Figure 13. A histogram of the percentage of samples in polished sections from the Hole $395 A$ core that show cracking in the titanomagnetite grains. The format of this figure is the same as that for Figure 12. None of the samples with Curie temperatures below $200^{\circ} \mathrm{C}$ show any cracking associated with low-temperature oxidation, whereas most of the samples with Curie temperatures above $225^{\circ} \mathrm{C}$ show at least some cracking of the titanomagnetite/titanomaghemite grains.

Sample: $395 \mathrm{~A}-4-1,91-93 \mathrm{~cm}(8)$

Lithologic description: Recrystallized gabbro.

Opaque mineralogy: The major opaque minerals are large euhedral grains of magnetite, 20 to $100 \mu \mathrm{m}$ in size. Some of these grains have ilmenite lamellae on the (111) planes, and some contain patches or rods of small hematite grains. Granulation is common within the large magnetite grains, particularly close to grain edges or cracks. Most of the large magnetite grains show low-temperaturealtered rims and abundant cracking within the grains (Stages 2 and 3 ). Some magnetite grains are partially eroded and replaced with non-opaque material (Stages 4 and 5). Occasional magnetite grains have abundant small black rods (spinel ?) oriented (100). A second generation of magnetite rods $(1 \times 10 \mu \mathrm{m})$ appears within the silicate grains that appear to be crystallographically oriented. Ilmenite is present, both as lamellae within the magnetite grains and as large (up to $200 \mu \mathrm{m}$ ) separate grains. Occasional thin rods of rutile (1 X $20 \mu \mathrm{m})$ are present. This sample appears to have undergone high(ilmenite lamellae), intermediate-(granulation), and low(maghemitization) temperature oxidation. A splendid sample.

Sample: $395 \mathrm{~A}-4-2,56-58 \mathrm{~cm}$ (3)

Lithologic description: Serpentinized peridotite, largely talc and serpentine.

Opaque mineralogy: Major opaque mineral occurs as long filaments of titanium-free magnetite, generally 10 to $300 \mu \mathrm{m}$ long and 10 to $20 \mu \mathrm{m}$ or less in width. Some filaments are as narrow as $1 \mu \mathrm{m}$. These filaments are subparallel to each other, and appear to be oriented crystallographically with respect to the surrounding silicate grains. There is some red staining of the groundmass close to the opaque filaments and some evidence of maghemitization (Stages 2 and 3 ) of the magnetite. Although no euhedral or subhedral magnetite grains are evident, there are occasional anhedral rounded grains of magnetite, roughly $50 \mu \mathrm{m}$ in diameter. These also show evidence of low-temperature oxidation (Stages 2 and 3). No ilmenite phases were observed. 


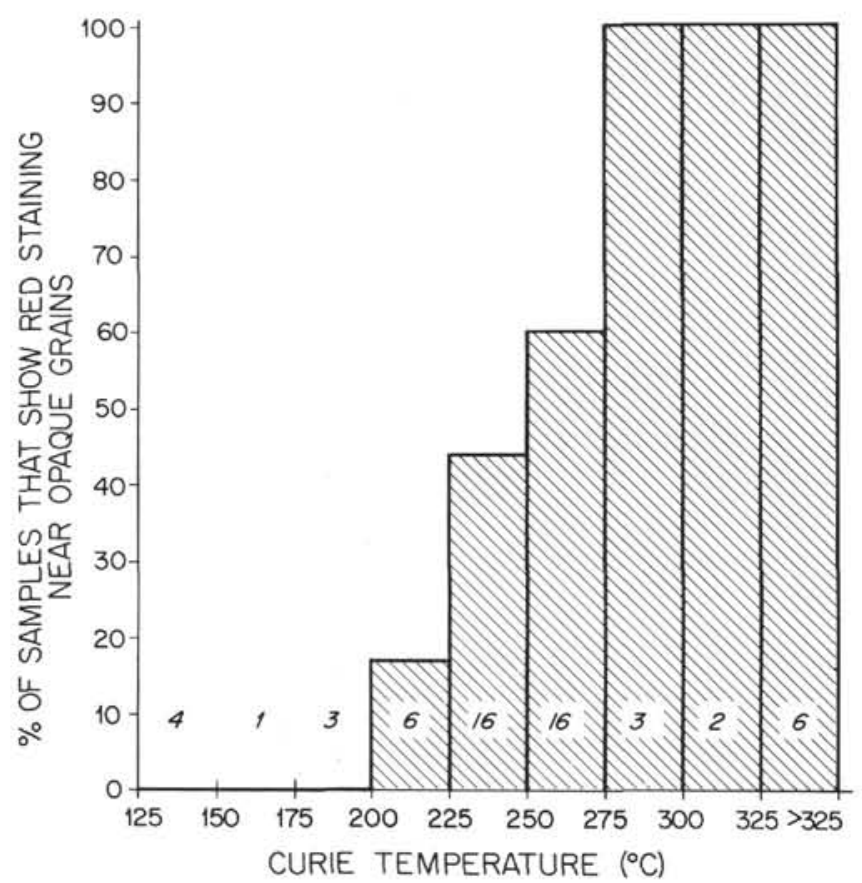

Figure 14. A histogram of the percentage of samples from the Hole $395 \mathrm{~A}$ core that show some form of red or yellow-red staining in the silicates surrounding the oxidized titanomaghemite grains. This staining is probably a result of migration of iron out of the opaque phase during oxidation. Most samples with Curie temperature above $250^{\circ} \mathrm{C}$ show some form of this staining.

Sample: 395A-5-1, 89-91 cm (16b)

Lithologic description: Fresh, fine-grained aphyric pillow basalt, no glassy or variolitic zones present.

Opaque mineralogy: Dominant mineral consists of large grains of fresh, unaltered titanomagnetite. Grain size tends to be generally 20 to $30 \mu \mathrm{m}$, but some grains are as large as 75 to $100 \mu \mathrm{m}$. Grain shape is usually euhedral to subhedral, but smaller grains are anhedral to skeletal. Grain color is the uniform dark gray characteristic of unaltered, Stage 1, high-titanium titanomagnetite. No cracks, discoloration, or altered rims within the grains are evident. In addition to the large titanomagnetite grains, there appears to be a smaller set of titanomagnetite grains, generally 1 to $10 \mu \mathrm{m}$ in size, anhedral in shape, and also apparently unaltered. This sample contains abundant sulfides, generally pyrite and pyrrhotite, as rounded anhedral grains. These grains can be as large as $50 \mu \mathrm{m}$ in diameter. Some pyrite grains show pyrrhotite lamellae. Some sulfide grains are rimmed with titanium-free magnetite, similar to those observed in the Leg 34 samples. There are occasional discrete grains of ilmenite, 10 to 20 $\mu \mathrm{m}$ in size and distinctively lath-shaped. None of the titanomagnetite grains shows any high- or low-temperature alteration features (Class 1. Stage 1).

Sample: $395 \mathrm{~A}-5-1,138-140 \mathrm{~cm}(19 \mathrm{~b})$

Lithologic description: Fine-grained aphyric pillow basalt.

Opaque mineralogy: Major opaque mineral is small anhedral to skeletal grains of titanomagnetite. Grain size is generally 2 to $5 \mu \mathrm{m}$, with rare grains to $10 \mu \mathrm{m}$. Titanomagnetite grains show some discoloration associated with low-temperature oxidation, and rare volume-change cracks (Stages 2 and 3 ). Some sulfides are present, generally pyrite grains, 5 to $10 \mu \mathrm{m}$ in size. Occasional laths of discrete ilmenite lamellae, 1 to $2 \mu \mathrm{m}$ wide and 10 to $20 \mu \mathrm{m}$ long (Class 1, Stages 2 and 3 ).

Sample: $395 \mathrm{~A}-5-2,6-8 \mathrm{~cm}$ (1)

Lithologic description: Fine-grained aphyric pillow basalt.

Opaque mineralogy: Major opaque mineral is unaltered grains of titanomagnetite, subhedral to skeletal, and generally about 5 to 10 $\mu \mathrm{m}$ in size. No oxidation features are apparent, and grains appear

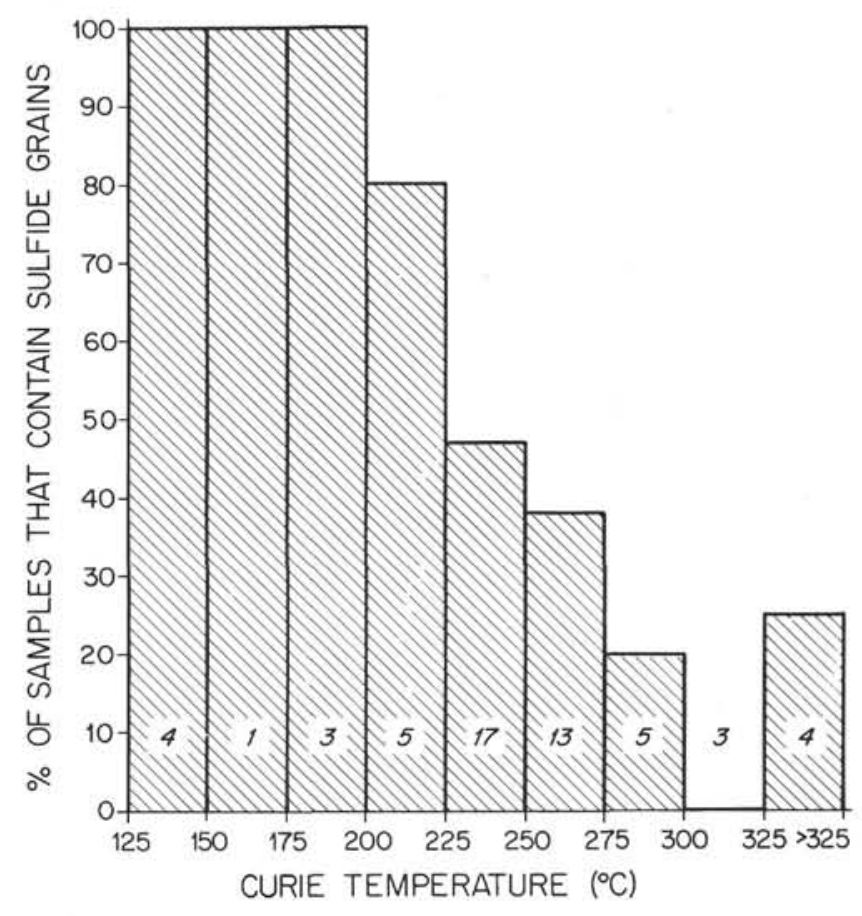

Figure 15. A histogram of the percentage of the Hole $395 \mathrm{~A}$ polished sections that give any evidence of the presence of sulfides on several traverses across the slide. The decrease in the presence of sulfides with increasing degree of low-temperature oxidation indicates that the sulfide phases are being oxidized and replaced by other phases.

extremely fresh. Occasional discrete laths of ilmenite are present, several micrometers wide and 10 to $25 \mu \mathrm{m}$ long. Sulfides, generally pyrite and pyrrhotite, are abundant. Sulfide grains appear unaltered. Titanomagnetite grains appear completely unoxidized (Class 1, Stage 1).

Sample: 395 A-11-1, 129-131 cm (8)

Lithologic description: Fine-grained, aphyric, pillow basalt.

Opaque mineralogy: Dominant opaque mineral is fine-grained (1 to $5 \mu \mathrm{m}$ ) skeletal titanomagnetite. Titanomagnetite grains appear unaltered, and no red staining of the groundmass is present (Class 1, Stages 1 or 2). Occasional ilmenite laths are present, several micrometers wide and $25 \mu \mathrm{m}$ long. Sulfides, including both pyrite and pyrrhotite, are abundant. Sample contains one enormous (300 $\mu \mathrm{m}$ in diameter) pyrite grain with pyrrhotite lamellae and a magnetite/ titanomagnetite rim. Groundmass silicates show a definite quench texture.

Sample: $395 \mathrm{~A}-13-1,97-99 \mathrm{~cm}$ (b)

Lithologic description: Plagioclase-olivine phyric pillow basalt.

Opaque mineralogy: Major opaque phase consists of fine ( 5 to 10 $\mu \mathrm{m})$ skeletal titanomagnetite grains that have been somewhat oxidized (Class 1, Stage 3 ). Some red staining occurs in the groundmass. Sulfide grains are present but rare, as are ilmenite laths.

Sample: $395 \mathrm{~A}-15-2,76-78 \mathrm{~cm}(1 \mathrm{k})$

Lithologic description: Plagioclase-olivine phyric basalt.

Opaque mineralogy: Coarse, low-temperature-oxidized, titanomagnetite grains, subhedral to euhedral in shape and from $20 \mu \mathrm{m}$ to $100 \mu \mathrm{m}$ in size, constitute the dominant phase present (Class 1, Stages 2 and 3). Some discoloration occurs in the titanomagnetite grains, and rare grains show incipient cracking of Stage 3. Sulfides, including pyrite and pyrrhotite rounded grains, are abundant. Some ilmenite laths occur as discrete phases.

Sample: $395 \mathrm{~A}-15-2,55-57 \mathrm{~cm}$ (li)

Lithologic description: Plagioclase-olivine phyric basalt.

Opaque mineralogy: Major phase consists of subhedral to euhedral grains of titanomaghemite, 20 to $75 \mu \mathrm{m}$ in size. Titanomaghemite grains show some discoloration, and volume-change 
cracks are rare. Titanomaghemite grains are very light gray. Sample appears generally unaltered, but some zones approach Stage 3 (Class 1, Stage 2). Ilmenite occurs as separate laths (some as big as $5 \mu \mathrm{m} \times$ $100 \mu \mathrm{m})$, but not as lamellae within the titanomagnetite grains. Some sulfide grains are present, but are largely oxidized and replaced; some red staining of the groundmass occurs around these altered grains. Some altered sulfides have magnetite/titanomagnetite rims. This sample seems to be very non-uniformly oxidized; some areas appear fresh (Stages 1 and 2), some more altered (Stage 3 and possibly 4).

Sample: $395 \mathrm{~A}-16-1,63-65 \mathrm{~cm}$ (1f)

Lithologic description: Plagioclase-olivine phyric basalt.

Opaque mineralogy: Major opaque phase is coarse grains of titanomaghemite, subhedral in shape and 25 to $100 \mu \mathrm{m}$ in size. Many low-temperature oxidation features are evident, including discoloration, volume-change cracks, replacement of parts of the opaque grains with non-opaque material (rarely), and red staining of the groundmass (Class 1, Stages 3 and 4). Some discrete ilmenite laths ( 5 to $10 \mu \mathrm{m}$ wide by 25 to $100 \mu \mathrm{m}$ long) are present. No sulfides are visible; some residual grains present may be replaced sulfide grains.

Sample: $395 \mathrm{~A}-18-1,142-144 \mathrm{~cm}$ (16)

Lithologic description: Plagioclase-olivine-CPX phyric basalt.

Opaque mineralogy: Fine-grained basalt with small ( 1 to $3 \mu \mathrm{m}$; rare grains to $10 \mu \mathrm{m}$ ) skeletal grains of low-temperature-oxidized titanomaghemite. Grain size is too small to see much detail, but titanomaghemite grains appear discolored and cracked (Class 1, Stage 3). Red staining of the groundmass. Most sulfide phases appear to be oxidized and replaced; only occasional grains of pyrrhotite present. One area of the sample contains several large ( 50 to $100 \mu \mathrm{m}$ ) rounded grains of pyrite that appear to be oxidizing to magnetite. Rare small laths of ilmenite also occur as a separate phase.

Sample: $395 \mathrm{~A}-22-2,132-134 \mathrm{~cm}(9 \mathrm{c})$

Lithologic description: Plagioclase-olivine-CPX phyric basalt.

Opaque mineralogy: Fine-grained basalt containing small ( 2 to $10 \mu \mathrm{m}$ ) skeletal titanomaghemite grains. Grains are light gray, partially discolored, and some of the larger ones show incipient cracking (Class 1, Stage 3). Sulfide grains are rare; most of those present are eroded in appearance and partially replaced. No ilmenite phases are evident.

Sample: $395 \mathrm{~A}-23-1,72-74 \mathrm{~cm} \mathrm{(5)}$

Lithologic description: Plagioclase-olivine-CPX phyric basalt.

Opaque mineralogy: Very fine grained basalt with small ( 1 to 10 $\mu \mathrm{m}$ ) basalt skeletal grains of titanomaghemite. Although the small grain size makes it difficult to observe alteration features, a few of the larger grains show discoloration and cracking (Class 1, Stage 3). Groundmass looks glassy, and in some instances shows red staining around the titanomaghemite grains. Sulfide grains are only rarely present (pyrite and pyrrhotite), and most are very altered and eroded in appearance. In one sample, there is a zone where several of the sulfide grains have altered to magnetite. No ilmenite grains are evident.

Sample: 395 A-24-1, 143-145 cm (5)

Lithologic description: Plagioclase-olivine-CPX phyric basalt.

Opaque mineralogy: Extremely fine grained basalt with very small (about $1 \mu \mathrm{m}$ ) skeletal opaque grains. Grain size is in general too small to see alteration features, but a few of the larger grains appear very light gray and have volume-change cracks (Class 1 ?, Stage 3 ). Little, if any, red staining of the groundmass is present. Only rare sulfide grains are present, and these seem to be altered. No ilmenite phases.

Sample: $395 \mathrm{~A}-25-1,85-87 \mathrm{~cm}(10 \mathrm{~b})$

Lithologic description: Plagioclase-olivine-CPX phyric basalt.

Opaque mineralogy: Extremely fine grained basalt with very small (less than $1 \mu \mathrm{m}$ ) skeletal (?) grains of titanomagnetite (?). Grain size is too small to see any alteration features (class?, stage?). No red staining of the groundmass is evident. No ilmenite or sulfide phases were observed.

Sample: $395 \mathrm{~A}-27-2,145-147 \mathrm{~cm}$ (11)

Lithologic description: Plagioclase-olivine-CPX phyric basalt.

Opaque mineralogy: Major opaque phase consists of anhedral to subhedral grains of slightly oxidized titanomagnetite, generally 25 $\mu \mathrm{m}$ in size, with occasional grains up to $50 \mu \mathrm{m}$. Some grains are discolored and occasionally show some volume-change cracks (not common). No red staining of the groundmass is evident (Class 1, Stage 2). Some separate ilmenite grains occur, 1 to $5 \mu \mathrm{m}$ wide and 10 to $25 \mu \mathrm{m}$ long. Some sulfides, including pyrite and pyrrhotite, are present, and some are altered.

Sample: 395A-28-1, 58-60 cm

Lithologic description: Plagioclase-olivine-phyric basalts.

Opaque mineralogy: Fine-grained basalt with skeletal titanomaghemite grains 1 to $3 \mu \mathrm{m}$ in size. Grain size is too small to identify any alteration features (class ?, stage ?). Red staining in the groundmass. Only rare sulfides present. No ilmenite phases observed.

Sample: 395A-28-1, 117-119 cm (9c)

Lithologic description: Plagioclase-olivine phyric basalt.

Opaque mineralogy: Fine-grained basalt with small ( 1 to $10 \mu \mathrm{m}$ ) skeletal grains of titanomaghemite. Titanomaghemite grains are discolored and show occasional cracking. Abundant red staining of the groundmass occurs around opaque grains (Class 1, Stage 3). The non-opaque silicates in the groundmass also appear to be altered. Some sulfide grains are present (pyrite and pyrrhotite) and some have been altered. One large sulfide grain $(\sim 100 \mu \mathrm{m})$ appears to be partially altered to magnetite.

Sample: 395A-31-1, 90-92 cm (7)

Lithologic description: Plagioclase-olivine phyric basalt.

Opaque mineralogy: Fine-grained basalt with small (1 to $5 \mu \mathrm{m}$ ) skeletal titanomaghemite grains. Small grain size makes identification of alteration features difficult, but some grains are discolored and several grains have very small incipient cracks (Class 1, Stage 2 ). No red staining of the groundmass specifically associated with the opaque phases, but the groundmass has a general reddish cast. Only rare sulfides present, and these seem to have been partially oxidized to magnetite. Only rare ilmenite grain present as a separate phase.

Sample: $395 \mathrm{~A}-32-1,54-56 \mathrm{~cm}$ (3a)

Lithologic description: Carbonate-clay-cemented breccia; polished section includes both clasts (plagioclase-olivine phyric basalt) and matrix material.

Opaque mineralogy: In the clasts, opaque minerals are small (5 to $10 \mu \mathrm{m}$; some grains to $20 \mu \mathrm{m}$ ) skeletal grains of oxidized titanomagnetite. These titanomagnetite grains generally have exsolved ilmenite lamellae on the (111) planes of the host mineral, indicating high-temperature oxidation (classes 2 and 3 ). Titanomagnetite grains without ilmenite lamellae are extremely cracked and eroded, and show extensive replacement by non-opaques. In the matrix material, there are occasional titanomagnetite grains that also show exsolved ilmenite lamellae. At the edges of the larger clasts and within the matrix, even the ilmenite lamellae appear partially eroded and cracked. In titanomagnetite grain from a clast, abundant ilmenite lamellae and several hematite grains were present as an alteration product (Classes 2 and 3, Stages 3 and 4). Red staining of the groundmass is common in both clasts and matrix. No sulfide phases are evident. Sample appears to have been exposed to both hightemperature (ilmenite lamellae) and low-temperature (cracking, maghemitization) oxidation.

Sample: $395 \mathrm{~A}-32-2,56-58 \mathrm{~cm}$ ( 1a)

Lithologic description: Carbonate-cemented breccia; polished section is mainly of one of the breccia clasts, a plagioclase-olivine phyric basalt.

Opaque mineralogy: Major opaque minerals in this clast are small ( 2 to $20 \mu \mathrm{m}$ ) skeletal grains of titanomaghemite. A systematic grains is less than $1 \mu \mathrm{m}$, and no alteration features could be observed. Groundmass has reddish stain around clusters of opaque grains. No sulfide grains observed. Groundmass has feathery quenched texture.

Sample: $395 \mathrm{~A}-48-1,55-57 \mathrm{~cm} \mathrm{(7b)}$

Lithologic description: Very fine grained aphyric basalt.

Opaque mineralogy: Major opaque mineral is small skeletal grains of titanomaghemite with an average size of about $10 \mu \mathrm{m}$. Some of the larger grains are discolored; patches of lighter gray occur in the dark gray grains. Occasional cracking is present, but not common (Class 1, Stage 2, occasional Stage 3). Red staining of groundmass is not evident. Sulfides (mainly pyrite) are not common. Some ilmenite laths occur as a separate phase. 


\section{Sample: $395 \mathrm{~A}-49-1,122-124 \mathrm{~cm}(9 \mathrm{a})$}

Lithologic description: Very fine grained aphyric basalt, cemented together as a glassy volcanic breccia.

Opaque mineralogy: Opaque minerals are very small ( 1 to $2 \mu \mathrm{m}$ in size) skeletal to anhedral titanomaghemite grains. Some of the larger grains are discolored, cracked, and partially replaced with non-opaque material (Class 1, Stages 3 and 4). Red staining of the groundmass around the opaques is common. Rare sulfide grains have been partially oxidized to magnetite. Sample appears to be highly oxidized and altered.

Sample: $395 \mathrm{~A}-49-2,101-103 \mathrm{~cm}$ (13a)

Lithologic description: Very fine grained sparsely phyric (rare plagioclase and olivine phenocrysts) basalt; sample is cut by carbonate vein.

Opaque mineralogy: A carbonate vein runs through center of polished section; alteration increases close to the vein. Throughout the sample the opaque minerals are small ( 2 to $3 \mu \mathrm{m}$; occasional grains to $10 \mu \mathrm{m}$ ), skeletal grains of titanomaghemite. Grains appear more altered close to the vein, but even next to the vein there are no ilmenite lamellae. Close to the vein, the titanomaghemite phases are cracked, discolored, eroded, and partially replaced with non-opaque material (Class 1, Stages 3 and 4). At a distance from the vein, grains are still cracked and discolored, but less replaced (Stage 3). Red staining of the groundmass is common, especially close to the vein. Some relict sulfide grains remain, but are largely replaced with magnetite and non-opaque material. No ilmenite phases are evident.

\section{Sample: 395 A-50-1, 140-142 cm (9)}

Lithologic description: Fine-grained aphyric basalt.

Opaque mineralogy: Major opaque phase is very small (2 to 5 $\mu \mathrm{m})$ skeletal grains of titanomaghemite. Grains are discolored, and an occasional larger grain shows some volume-change cracking. Some (not common) red staining of the groundmass occurs around clusters of opaque grains (Class 1, Stage 2 and occasional Stage 3). Groundmass has a feathery quenched texture. Sulfides are only rare, and are generally partially altered sometimes to magnetite.

Sample: 395A-54-1, 74-76 cm (10a)

Lithologic description: Very fine grained aphyric basalt with some carbonate-lined cracks.

Opaque mineralogy: Average grain size of opaques is $1 \mu \mathrm{m}$ or less, and no alteration features could be observed. Groundmass shows no obvious red staining, and has a very feathery quenched texture. In some areas of the section the groundmass looks entirely glassy. Sulfide grains are rare and extremely small.

Sample: 395 A-56-3, 117-119 cm

Lithologic description: Very fine grained aphyric basalt, with extensive fracturing and some secondary mineralization in hand sample.

Opaque mineralogy: Average grain size of opaques (titanomaghemite ?) is less than $1 \mu \mathrm{m}$, so that no alteration features could be observed. Groundmass has feathery quenched texture, and occasional red staining occurs near clusters of opaques. No sulfides are present.

\section{Sample: $395 \mathrm{~A}-57-1,110-112 \mathrm{~cm}(16 \mathrm{a})$}

Lithologic description: Very fine grained (sometimes glassy) aphyric basalt.

Opaque mineralogy: Opaque minerals are very small (about 1 search for grains with ilmenite lamellae (Class 2 or higher) yielded none. Some titanomaghemite grains show distinct volume-change cracks, and all are discolored and generally light gray (Class 1, some Stage 2, mostly Stage 3). Some red staining of the groundmass. Rare ilmenite grains present as a separate phase. No sulfide grains observed anywhere in this sample.

\section{Sample: $395 \mathrm{~A}-32-2,133-135 \mathrm{~cm}(9 \mathrm{~b})$}

Lithologic description: Carbonate-clay-cemented breccia; polished section is largely a plagioclase-olivine phyric basalt clast.

Opaque mineralogy: Breccia clast is very fine grained basalt with small ( 1 to $10 \mu \mathrm{m}$; mean grain size close to 2 or $3 \mu \mathrm{m}$ ) skeletal titanomaghemite grains. A systematic search for ilmenite lamellae within these grains (Classes 2 or 3 ) yielded none. Titanomaghemite grains are very bright, show uneven coloration, and in some instances have volume-change cracks. Red staining of the groundmass is common, especially close to the opaque grains. Cracking of the grains is not common (Class 1, Stages 2 and 3). No sulfide or ilmenite grains observed.

Sample: $395 \mathrm{~A}-33-1,34-36 \mathrm{~cm}$ (5a)

Lithologic description: Plagioclase-olivine phyric basalt.

Opaque mineralogy: An extremely fine grained basalt with very small (less than $1 \mu \mathrm{m}$ ) skeletal or anhedral titanomaghemite (?) grains. Grains are too small to see alteration features. Red staining of the groundmass is common. No sulfide or ilmenite phases evident.

Sample: $395 \mathrm{~A}-33-2,8-10 \mathrm{~cm}$ ( 1a)

Lithologic description: Plagioclase-olivine phyric basalt.

Opaque mineralogy: Very fine grained basalt with feathery quenched texture in the groundmass. Opaques are small ( 1 to $5 \mu \mathrm{m}$ ) skeletal titanomaghemite grains. Some of the larger grains show occasional cracking and non-uniform coloration (Class 1, mostly Stage 3, some Stage 2). Only rare sulfide grains, too small to identify. No ilmenite grains identified.

Sample: 395 A-33-2, 130-132 cm (15b)

Lithologic description: Fine-grained aphyric basalt or basalt breccia; parts of the sample are glassy.

Opaque mineralogy: Major opaque mineral consists of small ( 1 to $2 \mu \mathrm{m}$, occasionally larger) grains of titanomagnetite. Larger grains do not have any alteration features and appear uniformly dark gray. No red staining of the groundmass. Appears fresh and unoxidized (Class 1, probably Stage 1). Some sulfides present, but too small to identify. No ilmenite grains identified.

Sample: $395 \mathrm{~A}-37-1,109-111 \mathrm{~cm}$ (10b)

Lithologic description: Very fine grained aphyric basalt (glass on one end).

Opaque mineralogy: Opaque minerals are small ( 1 to $2 \mu \mathrm{m})$ anhedral to skeletal grains of titanomaghemite. Grain size too small to identify alteration features. Rare red staining of groundmass around clusters of opaque grains. Only very few sulfide grains observed.

Sample: $395 \mathrm{~A}-46-1,41-43 \mathrm{~cm}$ (1)

Lithologic description: Very fine grained aphyric basalt, taken from a core sample that has a zeolite vein with an associated corresponding alteration zone.

Opaque mineralogy: Dominant opaque phases are skeletal to anhedral titanomaghemite grains, about 1 to $3 \mu \mathrm{m}$ in size. Small size of grains prohibits examination of alteration features. Some red staining of the groundmass occurs close to opaque grains. No sulfides or ilmenite grains.

Sample: $395 \mathrm{~A}-47-1,124-126 \mathrm{~cm}$ (15)

Lithologic description: Very fine grained aphyric basalt with a carbonate veinlet, partially glassy in hand sample.

Opaque mineralogy: Opaque minerals occur as very fine grained (less than $1 \mu \mathrm{m}$ in size) titanomaghemites (?), too small to observe alteration features. Groundmass has red stain around clusters of opaque grains. No sulfides observed.

Sample: 395 A-47-2, 118-120 cm (12a)

Lithologic description: Very fine grained aphyric basalt; sample piece has carbonate vein.

Opaque mineralogy: Average size of these titanomaghemite $\mu \mathrm{m}$ ) skeletal and anhedral grains of titanomaghemite. Small size of grains prevents observation of alteration features in any but the largest, but no ilmenite lamellae are evident and some cracking and discoloration occur (Class 1, Stage 3). The entire groundmass has a reddish color that is not obviously associated with the opaque grains. No sulfide or ilmenite grains were observed.

Sample: $395 \mathrm{~A}-57-1,127-129 \mathrm{~cm}$ (16b)

Lithologic description: Very fine grained (sometimes glassy) aphyric basalt.

Opaque mineralogy: Opaque minerals are very small ( 2 to $5 \mu \mathrm{m}$ ) anhedral and skeletal grains of titanomaghemite. Some discoloration is evident, but no cracking is visible in the larger grains (Class 1, Stage 2). No red staining of the groundmass. Occasional small laths of ilmenite occur as separate grains. Only rare sulfide grains are present.

Sample: $395 \mathrm{~A}-58-2,115-117 \mathrm{~cm}(6 \mathrm{i})$

Lithologic description: Hyaloclastite; basaltic glass fragments in a matrix of altered glass. 
Opaque mineralogy: All the opaque grains are smaller than the optical limit. No sulfides or ilmenite grains visible, and no red staining in the groundmass. Sample appears to be completely glassy.

Sample: 395 A-60-3, $34-36 \mathrm{~cm}$ (2)

Lithologic description: Fine-grained aphyric basalt.

Opaque mineralogy: The opaque minerals are small ( 1 to $3 \mu \mathrm{m}$ ) skeletal and anhedral grains of titanomaghemite. Larger grains show some discoloration and occasional cracking (Class 1, Stages 2 and 3). Groundmass has a reddish tint not clearly associated with any particular opaque minerals. Very few sulfide grains present, and these are partially altered and oxidized to magnetite. Occasional small lath of ilmenite present as a separate phase.

Sample: 395A-60-3, 137-139 cm (10)

Lithologic description: Very fine grained aphyric basalt; some glass and clay-lined cracks present in the sample.

Opaque mineralogy: All the opaque grains appear to be smaller than $1 \mu \mathrm{m}$, and no alteration features are visible. Groundmass shows a feathery quenched texture, and has a general reddish cast. No red staining associated with the opaque phases is evident. No sulfides or ilmenite phases.

Sample: $395 \mathrm{~A}-61-1,117-119 \mathrm{~cm}$ (1)

Lithologic description: Fine-grained aphyric basalt (sample directly above upper dolerite intrusion).

Opaque mineralogy: Major opaque mineral is very small ( 1 to 3 $\mu \mathrm{m}$ ) anhedral to skeletal grains of titanomaghemite. Some of the larger grains are discolored and have cracks (Class 1, Stages 2 and $3)$. Groundmass has feathery quenched texture and a general reddish cast. No red staining directly attributed to the opaques. No sulfide grains.

Sample: $395 \mathrm{~A}-61-2,74-76 \mathrm{~cm}(5)$

Lithologic description: Plagioclase-olivine-CPX doleritic basalt.

Opaque mineralogy: Dominant opaque mineral consists of relatively large grains of titanomagnetite. Grain size and shape range from $5 \mu \mathrm{m}$ (skeletal) to as large as $100 \mu \mathrm{m}$ (euhedral). Average grain size must be close to 20 or $30 \mu \mathrm{m}$. Some titanomagnetite grains show well-defined ilmenite lamellae, though many others do not. Only slight evidence of low-temperature alteration-occasional grains show limited discoloration and incipient cracking (Classes 1 and 2, Stages 1 and 2). Sulfides, both pyrite and pyrrhotite, are abundant. Ilmenite present, both as lamellae within the titanomagnetite grains and as a separate phase.

Sample: $395 \mathrm{~A}-61-3,75-77 \mathrm{~cm}(6)$

Lithologic description: Plagioclase-olivine-CPX doleritic basalt.

Opaque mineralogy: High-temperature-oxidized titanomagnetite, the dominant opaque mineral in this sample, occurs as coarse grains. Grain size is approximately $50 \mu \mathrm{m}$, and many grains are as large as $100 \mu \mathrm{m}$, generally euhedral in shape. The titanomagnetite grains have abundant well-developed ilmenite exsolution lamellae. Some grains show an intermediate-temperature granulation instead of welldeveloped lamellae. Other grains show characteristic low-temperature cracking and discoloration (Classes 1, 2, 3, Stages 2 and 3, granulation present). Sulfide grains, mostly pyrite and pyrrhotite, are abundant. Some sulfide grains have magnetite rims and/or are corroded in appearance. Ilmenite is present, largely as lamellae within the titanomagnetite grains.

Sample: 395A-61, CC, 13-15 cm (2)

Lithologic description: Plagioclase-olivine-CPX doleritic basalt.

Opaque mineralogy: Dominant opaque mineral is titanomagnetite, in very large euhedral grains. Some grains are 10 to $20 \mu \mathrm{m}$ (skeletal to subhedral), but most are 50 to $100 \mu \mathrm{m}$. Some grains show ilmenite exsolution lamellae, but these are neither common nor well-developed. Discoloration and cracking resulting from lowtemperature oxidation is common. Some grains show a type of granulation that may be intermediate-temperature alteration. Most ilmenite exsolution lamellae are curved and not well formed. This sample seems to have been subjected to only a moderate amount of high-temperature oxidation and to a substantial amount of lowtemperature oxidation (between Class 1 and Class 2, Stage 3, granulation present). Some sulfide grains are present (pyrite and pyrrhotite), but are not common and are altered. Several large (200 $\mu \mathrm{m}$ by $20 \mu \mathrm{m}$ ) laths of ilmenite occur as a separate phase.
Sample: 395A-61, CC, $53-55 \mathrm{~cm}$ (5)

Lithologic description: Plagioclase-olivine-CPX doleritic basalt.

Opaque mineralogy: Opaque phase is titanomagnetite that has been subjected to moderate amounts of both high-temperature and low-temperature oxidation. Some titanomagnetite grains show poorly developed ilmenite lamellae, and some show discoloration and cracking (Classes 1 and 2, Stages 2 and 3). Some red staining of the groundmass. Grain size of titanomagnetites is bimodal: the smallest is close to 5 to $10 \mu \mathrm{m}$ (skeletal and anhedral) and the largest between 50 and $100 \mu \mathrm{m}$ (generally euhedral). Both pyrite and pyrrhotite are common, and sulfide grains appear altered and eroded.

Sample: $395 \mathrm{~A}-62-1,40-42 \mathrm{~cm}(5)$

Lithologic description: Fine-grained aphyric basalt that occurs between the upper and lower dolerite intrusions.

Opaque mineralogy: An extremely fine grained sample which has a very feathery quenched texture in the groundmass. The opaque minerals are very small ( 1 to $4 \mu \mathrm{m}$ ) skeletal to anhedral grains of oxidized titanomagnetite. The small grain size precludes positive identification, but some of the larger grains appear to have ilmenite exsolution lamellae. Most opaque grains show patchy structures of darker material within the oxidized titanomagnetite grains. Occasionally some of the larger grains have evident replacement cracks (Class 2 . Stages 2 and 3). Red staining of the groundmass is common and pronounced. No original sulfides are present. Sample contains vesicles filled with partially opaque orange and green material. Bright red veins (iron oxides/hydroxides ?) occur throughout the sample. Groundmass shows feathery quenched texture.

Sample: $395 \mathrm{~A}-62-1,84-86 \mathrm{~cm}$ (7)

Lithologic description: Plagioclase-olivine-CPX doleritic basalt, the upper part of the lower dolerite unit.

Opaque mineralogy: Opaque mineral grains are very small (2 to $5 \mu \mathrm{m}$ skeletal to anhedral grains of oxidized titanomagnetite. Groundmass is not feathery quenched texture, but is holocrystalline and even coarse grained. Titanomagnetite grains are small and similar to those found in pillow basalt. Grain size is too small to identify any ilmenite lamellae, but an occasional larger grain is discolored and cracked. One grain has been partially replaced by non-opaque material (class 1 [?], Stages 3 and 4). Groundmass shows red staining close to some (not all) opaques. Some relict sulfide grains, largely altered and eroded, are present.

Sample: $395 \mathrm{~A}-63-1,38-40 \mathrm{~cm} \mathrm{(3c)}$

Lithologic description: Plagioclase-olivine-CPX doleritic basalt.

Opaque mineralogy: Dominant opaque phase consists of coarsegrained ( 50 to $100 \mu \mathrm{m}$ ), euhedral, oxidized titanomagnetite. No ilmenite exsolution lamellae are present, but abundant low-temperature oxidation is evident; this includes discoloration and cracking in most grains (Class I, Stage 3). Some red staining of the groundmass occurs near the opaque grains.

Sample: $395 \mathrm{~A}-63-2,2-4 \mathrm{~cm}$ ( 1a)

Lithologic description Plagioclase-olivine-CPX doleritic basalt.

Opaque mineralogy: Dominant opaque mineral is coarse-grained (50 to $100 \mu \mathrm{m}$ ) titanomagnetite. Grain shape is largely euhedral. Some titanomagnetite grains have been oxidized at low temperature; some discoloration and volume-change cracks. No ilmenite exsolution lamellae (Class 1, Stages 2 and 3). Some sulfide grains (pyrite and pyrrhotite) present, some of which have been altered and oxidized. No red staining of the groundmass was observed.

Sample: $395 \mathrm{~A}-63-3,50-52 \mathrm{~cm}$ (1b)

Lithologic description: Plagioclase-olivine-CPX doleritic basalt.

Opaque mineralogy: The titanomagnetite grains in this sample occur in a wide range of sizes and shapes, from $10 \mu \mathrm{m}$ (skeletal and anhedral) to $100 \mu \mathrm{m}$ (generally euhedral). An occasional grain shows poorly developed ilmenite exsolution lamellae. These lamellae are not common. Most titanomagnetite grains show low-temperature oxidation features, including discoloration and (common) volumechange cracks (Classes 1 and 2, Stages 2 and 3). There is some red staining of the groundmass, but it is not always associated with the opaque grains.

Sample: $395 \mathrm{~A}-63-4,32-34 \mathrm{~cm}$ (1c)

Lithologic description: Plagioclase-olivine-CPX doleritic basalt.

Opaque mineralogy: Major opaque phase consists of large ( 50 to $100 \mu \mathrm{m})$, oxidized, euhedral shaped, titanomagnetite grains. Some 
grains have poorly developed ilmenite exsolution lamellae, generally curved. Most grains contain extensive mottling and discoloration, as well as volume-change cracks. Some cracks show partial replacement of the opaque material by non-opaque material. The low-temperature cracks clearly occurred after the ilmenite formation, since some of the cracks cut across both the host magnetite and the ilmenite lamellae (Class 2, Stages 3 and 4). No sulfides were observed.

Sample: 395 A-64-1, 106-108 cm (1b)

Lithologic description: Plagioclase-olivine-CPX doleritic basalt.

Opaque mineralogy: Grain size of titanomagnetite ranges from $10 \mu \mathrm{m}$ (skeletal to anhedral) to as large as $100 \mu \mathrm{m}$ (subhedral to euhedral). Most grains are about $50 \mu \mathrm{m}$ in size. Titanomagnetite appears very dark gray and unoxidized. An occasional grain shows some low-temperature alteration features, but these are not common (Class 1, Stage 1). Abundant sulfide grains, both pyrite and pyrrhotite, are present, and are only rarely altered. Sample appears very unoxidized.

Sample: $395 \mathrm{~A}-64-2,56-58 \mathrm{~cm}$

Lithologic description: Plagioclase-olivine-CPX doleritic basalt sample taken from near the bottom contact of the lower dolerite intrusion.

Opaque mineralogy: Grain size of this sample is smaller than the previous dolerite samples. Most of the titanomagnetite grains are 10 to $15 \mu \mathrm{m}$ in size; some are as large as $50 \mu \mathrm{m}$. Grain shape is largely subhedral. Most titanomagnetite grains have ilmenite exsolution lamellae, well developed along the (111) planes of the host mineral. In addition to this high-temperature oxidation feature, most grains also show a later, low-temperature oxidation phase, in which cracking and discoloration are common (Classes 2 and 3, Stages 2 and 3). Sulfide phases are rare and appear altered. Occasional ilmenite lath present as a separate phase.

Sample: $395 \mathrm{~A}-64-2,135-137 \mathrm{~cm}$

Lithologic description: Fine-grained aphyric basalt. This sample is from the contact between the lower dolerite intrusion and the unit just below.

Opaque mineralogy: The opaque minerals consist of very small (2 to $10 \mu \mathrm{m}$, averaging about $5 \mu \mathrm{m}$ ) skeletal grains of oxidized titanomagnetite. The fine grain size does not allow observation of any ilmenite lamellae, but some of the larger grains are discolored and cracked (Class 1 [?], Stages 2 and 3). Entire groundmass has a reddened appearance. Sample appears highly oxidized. Groundmass has feathery quenched texture. No sulfides are present.

Sample: $395 \mathrm{~A}-64-3,8-10 \mathrm{~cm}$

Lithologic description: Very fine grained aphyric basalt.

Opaque mineralogy: Titanomaghemite grains are very small ( 2 to $5 \mu \mathrm{m} ; 3 \mu \mathrm{m}$ is average) and skeletal in shape. There are a few large magnetite (?) grains close to vesicles that are pseudomorphic after sulfide grains. Some of the skeletal titanomaghemite grains are discolored and cracked. No ilmenite exsolution lamellae observed (Class 1, Stage 3 ). No red staining of the groundmass, but all the silicate grains have a definite yellowish cast not observed in samples higher in the core. Only relict sulfide grains present.

\section{Sample: $395 \mathrm{~A}-64-3,42-44 \mathrm{~cm}$}

Lithologic description: Fine-grained aphyric basalt; some fractures are filled with clay and carbonate veining.

Opaque mineralogy: Major opaque mineral consists of small ( 5 to $10 \mu \mathrm{m}$, average around $6 \mu \mathrm{m}$ ) skeletal grains of titanomaghemite). These opaque grains are very bright, mottled, and have occasional volume-change cracks. No ilmenite lamellae are evident (Class 1, Stage 3). Sulfides are rarely present; most have been altered to magnetite. Red staining of the groundmass occurs around some opaque grains, particularly around some of the altered sulfides. The groundmass has a feathery quenched texture and the same pronounced yellowish cast as the previous sample. Occasional separate grains of ilmenite are present.

Sample: $395 \mathrm{~A}-64-4,67-69 \mathrm{~cm}$

Lithologic description: Fine-grained aphyric basalt in which secondary clays, chlorite, and possibly zeolites fill abundant fractures.

Opaque mineralogy: The titanomaghemite grains in this sample are very bright gray, small ( 5 to $25 \mu \mathrm{m}$; average about $10 \mu \mathrm{m}$ ), and skeletal in shape. No ilmenite exsolution lamellae are present, but there is abundant evidence of low-temperature oxidation, including mottled coloring, volume-change cracks, and occasional red staining of the groundmass (Class 1. Stage 3). The groundmass has a feathery quenched texture and the same (but less pronounced) yellowish cast as the previous sample. No sulfide grains are present, only a few magnetite grains that may be relict sulfide phases.

Sample: $395 \mathrm{~A}-64-4,124-126 \mathrm{~cm}$

Lithologic description: The titanomaghemite grains in this sample are very bright gray, slightly larger than the previous sample (average about $12 \mu \mathrm{m}$ ), and skeletal in shape. No ilmenite exsolution lamellae are present, but abundant low-temperature oxidation features are evident (mottled coloration, occasional cracking, and rare red staining of the groundmass) (Class 1, Stages 2 and 3). No sulfide phases are present, but some magnetite grains look as if they are relict altered sulfides. Red staining of the groundmass is common around these former sulfide grains. Some quenched texture in the groundmass is present, but it is not as "feathery" as the previous sample. Groundmass has slight yellowish cast, similar to previous samples. An occasional discrete grain of ilmenite is present.

Sample: 395A-65-1, 148-150 cm

Lithologic description: Very fine-grained aphyric basalt that appears intensely altered in hand sample, with abundant fractures filled by secondary clays, chlorite, and possibly zeolites.

Opaque mineralogy: The opaque minerals in this sample are small ( 2 to $5 \mu \mathrm{m}$, occasionally as large as $20 \mu \mathrm{m}$ ), skeletal grains of titanomaghemite. Abundant features of low-temperature oxidation including a bright, but uneven coloration and cracking within grains (Class 1 . Staqes 2 and 3 ). There is only occasional red staining of the groundmass, generally near altered relics (generally magnetite) of sulfide grains. No unaltered sulfides are present. The groundmass has the same yellowish cast as the previous samples.

Sample: $395 \mathrm{~A}-65-2,13-15 \mathrm{~cm}$

Lithologic description: Fine-grained aphyric basalt with alteration features similar to Sample $395 \mathrm{~A}-65-1,148-150 \mathrm{~cm}$.

Opaque mineralogy: This sample has a large white vein (carbonate/zeolite?) running through the center of the polished section. The titanomaghemite grains in the sample are small ( 5 to $10 \mu \mathrm{m}$ average close to $5 \mu \mathrm{m})$ and skeletal in shape. No ilmenite lamellae were observed in any grains. Opaque grains have bright, uneven gray color, and most of the larger grains show cracking. There is some red staining of the groundmass associated with the opaques, especially close to the vein. An occasional titanomaghemite grain close to the vein shows some granulation features, but this is not common (Class 1. Stage 3 ). Sulfide phases are not evident, but some magnetite grains may be sulfide relics. The vesicles of this sample are not filled.

Sample: $395 \mathrm{~A}-65-2,31-33 \mathrm{~cm}$

Lithologic description: Fine-grained aphyric basalt, with alteration features similar to Sample 395A-65-1, 148-150 cm.

Opaque mineralogy: The titanomaghemite grains in this sample are small ( 2 to $7 \mu \mathrm{m}$ average about $5 \mu \mathrm{m}$ ), and skeletal to anhedral in shape. No ilmenite exsolution lamellae are generally present, but there is evidence of low-temperature oxidation; the grains have a bright, uneven coloring. Cracking is not generally present and there is no red staining of the groundmass. One atypically large titanomagnetite grain $(25 \mu \mathrm{m})$ has ilmenite lamellae, but this is the only grain with this feature (Class 1, Stage 2). No sulfide grains are present, but some magnetite grains may be altered relict sulfide phases.

Sample: $395 \mathrm{~A}-66-1,83-85 \mathrm{~cm}$

Lithologic description: Fine-grained aphyric basalt with alteration features similar to the previous sample.

Opaque mineralogy: The opaque minerals in this sample are very small $(1$ to $5 \mu \mathrm{m})$ skeletal grains of titanomaghemite. These grains are somewhat lighter in color than unaltered titanomagnetite, but the sample looks relatively unoxidized. No cracking or red staining twas observed (Class 1, Stage 2). Occasional sulfide grains, pyrite and pyrrhotite, are present. Occasional discrete laths of ilmenite occur as a separate phase.

Sample: $395 \mathrm{~A}-66-2,21-23 \mathrm{~cm}$

Lithologic description: Fine-grained aphyric basalt with fractures containing clays, chlorite, and possibly zeolites.

Opaque mineralogy: The opaque mineral in this sample occurs as very small (average about $2 \mu \mathrm{m}$ ) skeletal grains of titanomaghemite. These grains show no ilmenite lamellae, but have the uneven bright 
gray color and cracking associated with low-temperature oxidation. An occasional grain shows a granulated texture, but this is not common (Class 1, Stages 2 and 3, some granulation).

Sample: $395 \mathrm{~A}-66-2,85-87 \mathrm{~cm}$

Lithologic description: Fine-qrained aphyric basalt with intense alteration features, including fractures filled with clays, chlorite, and possibly zeolites.

Opaque mineralogy: This polished section contains a white vein with small pieces of volcanic glass imbedded in it. The opaque mineral in the crystalline portion of the sample consists of highly oxidized titanomaghemite grains. Grains are skeletal in shape and 2 to $3 \mu \mathrm{m}$ in size. Grain size is almost too small to distinguish any alteration features, but no ilmenite lamellae are obvious in the larger grains; these grains are an uneven bright gray, and some cracking is present. An occasional grain shows some granulation, although this is not common (Class 1 [?], Stage 3, some granulation). The entire groundmass of the sample has a reddish cast, although this is not clearly associated with the opaques. No unaltered sulfide grains were observed.

Sample: 395A-66-3, 110-112 cm (11)

Lithologic description: Fine-grained aphyric basalt, with filled fractures and vesicles similar to previous samples.

Opaque mineralogy: This polished section has a zeolite (?) vein on one edge. The opaque mineral is titanomaghemite; grains are skeletal in shape and 10 to $25 \mu \mathrm{m}$ in size. The grains become brighter gray closer to the vein. No ilmenite lamellae were observed in any grains, even close to the vein. The titanomaghemite grains are a bright uneven gray, and most show volume-change cracking. Some cracks are filled with non-opaque material. No evidence of granulation within the grains (Class 1, stages 3 and 4). The groundmass has a yellowish cast, similar to the previous samples. Sulfides are altered to magnetite, and show red staining of the groundmass associated with this alteration. Some discrete grains of ilmenite are present as a separate phase. The vesicles of this sample are filled with beautiful zeolite (?) crystals. The olivine crystals are extremely altered, and in some cases the alteration is generating a very fine opaque phase (symplectic magnetite?). This alteration is more pronounced close to the zeolite (?) vein.

Sample: $395 \mathrm{~A}-67-1,83-85 \mathrm{~cm}$

Lithologic description: Fine-grained aphyric basalt so highly fractured that it was labeled a breccia in the Initial Core Description. Secondary minerals (chlorite plus zeolites?) fill most of the fractures.

Opaque mineralogy: The opaque minerals in this sample are very small (less than $1 \mu \mathrm{m}$ ), and no alteration features could be observed. The larger opaque grains appear to be skeletal or anhedral. No sulfides were observed. Groundmass is feathery and no red staining is evident.

Sample: $395 \mathrm{~A}-67-2,88-90 \mathrm{~cm}$

Lithologic description: Fine-grained aphyric basalt with fractures and alteration similar to the previous sample.

Opaque mineralogy: The opaque minerals are small ( 5 to $10 \mu \mathrm{m}$; average closer to $5 \mu \mathrm{m}$ ) skeletal grains of titanomaghemite. Grain color is a very bright, uneven gray and cracking occurs in some grains (Class 1, Stage 3). The vesicles appear filled and there is some red staining near the opaques. The entire groundmass has a general yellowish cast. No sulfides are present. 